\title{
BINGKAI KURUS REALISME STRUKTURAL EPISTEMIK
}

\author{
KARLINA SUPELLI*
}

\begin{abstract}
Abstrak: Di tengah-tengah perdebatan panjang antara realisme dan antirealisme dalam filsafat ilmu, realisme struktural (RS) diajukan sebagai gagasan yang terbaik dari keduanya. Versi epistemik RS (RSE) berpendapat bahwa kita memiliki alasan yang baik untuk percaya bahwa teori memiliki struktur yang tepat, yaitu bahwa wujud dan struktur yang dipostulatkan oleh teori betul-betul ada. Namun demikian, RSE tidak mengajukan dakuan epistemik menyangkut hakikat wujud yang melandasi struktur. Semua pengetahuan mengenai dunia fisis adalah pengetahuan tentang struktur. Dalam tulisan ini penulis memberi tinjauan tentang RSE dan beberapa argumen yang menolak RSE. Belajar dari sejarah fisika zarah, penulis akan memperlihatkan bahwa struktur menunjuk ke sifatsifat mendasar yang dimiliki oleh komponen-komponennya dan dengan demikian menyediakan jalur epistemik bagi wujud yang relasi-relasinya mendefinisikan struktur. Meski demikian, struktur matematis sebuah teori hanya memungkinkan kita membangun pengetahuan tentang wujudwujud yang tidak teramati sebagai "objek" dan bukan objek-objek partikular.
\end{abstract}

Kata-kata Kunci: Realisme, anti-realisme, realisme struktural epistemik, argumen tanpa keajaiban, meta-induksi pesimistik, wujud takteramati.

Abstract: In the lengthy debate between antirealism and realism in the philosophy of science, structural realism (SR) has been suggested as "the best of both worlds." The epistemic version of SR (ESR) holds that we have good reason to believe that our most successful scientific theories are structurally correct - that the entities and structures postulated by a theory actually exist, and yet it makes no epistemic claim about the nature of the underlying entities. All that we can know is the structure of

* Karlina Supelli, Program Pascasarjana, Sekolah Tinggi Filsafat Driyarkara, Cempaka Putih Indah 100 A, Jembatan Serong, Rawasari, Jakarta 10520. E-mail: karlina. supelli@gmail.com 
the physical world. In this article I present an overview of ESR and a number of arguments that have been brought up against it. Drawing lessons from the history of contemporary physics, I will show that "structure" points to the fundamental properties of its constituents and thus provides an epistemic access to the nature of those entities whose relations define structure in the first place. Nevertheless, the mathematical structure of a theory enables us only to construe knowledge of an unobservable entity as "object," and not this or that particular object.

Keywords: Realism, anti-realism, epistemic structural realism, no miracle argument, pesimistic meta-induction, unobservable entity.

\section{PENDAHULUAN}

Dalam sebuah konferensi, pakar antropologi Frederique ApffelMarglin mengkritik keras program vaksinasi cacar oleh pemerintah kolonial Inggris di India karena menyingkirkan praktik inokulasi sebagai bagian dari ritual pemujaan Dewi Sitala; vaksinasi adalah contoh bagaimana pengetahuan Barat mengabaikan perbedaan. Martha Nussbaum yang hadir dalam konferensi itu berkomentar, "bukankah lebih baik sehat dari pada sakit, hidup ketimbang mati." Apffel-Marglin menjawab bahwa ilmu kedokteran Barat menandai corak universalis ilmu pengetahuan Barat yang dikuasai oleh oposisi biner. Dalam makalahnya, Apffel-Marglin menulis, "dalam masyarakat India tidak ada dikotomi sakit/sehat ... Sitala adalah penyakit sekaligus kesembuhannya ... Superioritas sistem keilmuan lahir dari corak hegemonisnya," demikian ApffelMarglin menyimpulkan. ${ }^{1}$

Ilustrasi di atas penulis pinjam untuk memperlihatkan salah satu bentuk ekstrim anti-realisme. Anti-realisme menolak ilmu sebagai upaya

1 Martha C. Nussbaum, Sex and Social Justice (Oxford, Oxford University Press, 1999), pp. 35-36. Inokulasi (variolasi) adalah praktik menggores kulit orang sehat dengan cairan lesi cacar dari penderita. Inokulasi dapat menimbulkan kekebalan tetapi risiko tertular dan mendatangkan kematian cukup tinggi. Kisah Nussbaum penulis lengkapi dengan paparan Frederique Apffel-Marglin dalam konferensi itu, "Smallpox in Two Systems of Knowledge," UNU/Wider Planning Meeting on Systems of Knowledge as Systems of Domination (Juli 1987), pp. 25, 44, 51. 
untuk memberi penjelasan tentang dunia yang kian mendekati kebenaran seiring dengan kemajuan ilmu. Sebaliknya dengan realisme. Kalau ditinjau dari ilustrasi di atas, para realis akan mengatakan bahwa untuk bersikap positif terhadap temuan-temuan keilmuan, sekurang-kurangnya orang perlu mengakui bahwa kesuksesan ilmu bukan sekadar buah kesepakatan sosial-politik ilmuwan. Untuk mendukung pandangannya, realis perlu menunjukkan bahwa ada bagian teori yang memerikan aspek realitas dengan tepat. Realis perlu menunjukkan bahwa ilmu mengalami kesuksesan karena mengacu ke wujud-wujud alami (natural kind) ${ }^{2}$ dan bukan ke wujud fiktif karangan para ilmuwan. Upaya itu tidak mudah karena teori tidak hanya mencantumkan objek-objek yang langsung terlihat seperti meja, sepatu, bunga, manusia, dan lain sebagainya. Teori juga berisi pernyataan tentang elektron, quark, titik ruangwaktu, medan elektromagnetik, kesadaran, akal budi, dan lain-lain yang tidak dapat langsung diamati. Matematikawan Bernhard Riemann, contohnya, mengajukan geometri ruang sebagai wujud fisis.

Pernyataan yang sering dikutip untuk mendukung realisme sekaligus yang paling banyak mendapat tantangan adalah rumusan singkat Hilary Putnam, "realisme adalah satu-satunya filsafat yang membuat kesuksesan ilmu bukan merupakan keajaiban." ${ }^{3}$ Argumen tanpa keajaiban (no miracle argument; selanjutnya NMA) ini bermaksud membela kehandalan metode keilmuan dengan mengatakan bahwa wujud-wujud takkasat indera yang dipostulatkan oleh teori-teori yang sudah matang mempunyai acuan nyata di dunia. Bagaimana bom atom dapat menghancurkan Hiroshima dan Nagasaki seandainya "atom" dalam teori fisika tidak mengacu dengan benar ke atom yang ada di dunia? NMA seiring sejalan

2 Penulis menggunakan istilah wujud alami (natural entity) untuk menunjuk ke sesuatu yang ada dalam ruangwaktu, keberadaannya tidak bergantung pada syarat dan praktik epistemik, serta mempunyai identitas baik individual maupun non-individual. Wujud alami tidak termasuk proses, mekanisme, peristiwa dan relasi. Pengertian non-individualitas penting dalam mekanika kuantum karena sifat intrinsik zarah subatom yang tidak terbedakan dalam arti bahwa dua elektron dapat bertukar posisi tanpa menimbulkan perubahan fisika yang dapat dilacak.

3 Hilary Putnam, Mathematics, Matter and Method: Philosophical Papers, Vol. 1 (London: Cambridge University Press, 1975), p. 73. 
dengan argumen bahwa kesuksesan ilmu bukan ilusi atau karena sifat hegemonisnya belaka.

NMA mau menekankan bahwa teori-teori yang baik tidak saja menghasilkan ramalan yang tepat atas gejala, tetapi penjelasannya pun kian lama kian mendekati kebenaran. Namun realisme bukan tanpa masalah. Kajian terhadap sejarah ilmu menunjukkan bahwa ada teori yang meramal gejala dengan tepat tetapi wujud acuannya ternyata keliru atau malah terbukti tidak ada. Jika pengacuan bukan syarat niscaya bagi keberhasilan prediktif ilmu, realis berhadapan dengan situasi yang sulit. Di satu pihak teori itu sukses secara empiris, tetapi di lain pihak pernyataan ontologisnya salah. Dengan mengumpulkan fakta-fakta sejarah seperti itu, Larry Laudan mengajukan argumen untuk menyanggah NMA: lewat langkah induksi sederhana orang dapat menyimpulkan bahwa setiap teori yang paling berhasil pun suatu hari akan dinyatakan salah. Singkatnya, teori-teori itu lebih mungkin salah ketimbang benar. ${ }^{4}$ Argumen ini dikenal sebagai argumen meta-induksi pesimistik (selanjutnya IP).

Salah satu bentuk realisme yang mencoba menjawab tantangan IP dan kini banyak dibahas dalam filsafat ilmu adalah realisme struktural keilmuan (disingkat RS). RS membatasi tujuan ilmu sebagai pengungkapan jejaring relasi kongkret di antara wujud-wujud fisis yang ada di alam, dan bukan menyingkap identitas intrinsik atau hakikat wujudwujud itu. Dalam bingkai RS, Newton menemukan relasi-relasi di antara gejala yang kemudian ia rumuskan ke dalam persamaan matematis teori gravitasi. Bagi RSE bukan masalah bahwa Newton tidak mengetahui hakikat gravitasi ${ }^{5}$ karena ia mengemukakan dengan tepat relasi-relasi yang ada dalam alam. Di tataran epistemik, realisme struktural (RSE)

4 Larry Laudan, “A Confutation of Convergent Realism," Philosophy of Science 48 (1981): 33.

5 Newton mengakui hal itu. Ia menulis, "Saya belum berhasil menemukan penyebab yang menghasilkan sifat-sifat gravitasi ... cukuplah bahwa gravitasi betul-betul ada dan berlaku menurut hukum-hukum yang sudah kami jelaskan," [Isaac Newton, "General Scholium," Mathematical Principles of Natural Philosophy, trans. Andrew Motte (New York: Daniel Adee, 1846 [1729]), pp. 506-507]. 
membatasi pengetahuan sebagai pengetahuan tentang struktur. RSE tidak mengatakan bahwa wujud-wujud yang membangun struktur tidak ada atau tidak nyata. Wujud itu ada tetapi kita tidak mempunyai cara untuk mengetahui hakikatnya. Di tataran ontik, realisme struktural (RSO) menggeser komitmen ontologisnya ke struktur. RSO merupakan bentuk RS yang radikal karena menolak objek sebagai kategori ontologis dengan menyatakan hanya ada struktur. ${ }^{6}$

Tulisan ini merupakan tinjauan kritis atas RSE dan beberapa keberatan pokok yang muncul sejauh ini. Penulis juga akan menunjukkan bahwa RS adalah posisi yang aman untuk mengatasi salah satu argumen antirealis sehubungan dengan pergantian teori. Meski demikian, argumen RSE tidak cukup berdaging untuk menjelaskan kegiatan aktual ilmuilmu empiris, khususnya kalau kita mengambil ilustrasi dari perkembangan fisika zarah. Pendekatan struktural cukup berkembang dalam fisika dan membuka jalur epistemik yang mencengangkan ke kawasan wujud-wujud takteramati. Tulisan ini ditutup dengan kesimpulan bahwa fisikawan menangani masalah sebagai suatu sistem. Dalam sistem, relasi serta relata bukan dua kategori epistemik yang terpilah tajam sehingga pengetahuan tentang struktur pun menghasilkan tilikan yang berharga tentang sifatsifat wujud alami yang membangun relasi. Dengan demikian, wujud memiliki status epistemik yang tidak dapat diabaikan di dalam realisme.

Ada dua catatan untuk memulai tulisan ini. Pertama, para filosof ilmu memahami realisme dengan cara yang beragam. Untuk kepentingan tulisan ini cukup aman kalau penulis berpegang ke pengertian realisme epistemik keilmuan sebagai komitmen terhadap pandangan bahwa teoriteori terbaik atau teori-teori dalam ilmu-ilmu yang sudah matang ${ }^{7}$ mem-

6 RSO tidak penulis bahas dalam tulisan ini. RSO dikembangkan oleh Steven French and James Ladyman (2003). RSO memandang struktur sebagai satu-satunya realitas yang nyata. Dalam rumusan Ladyman, "Realisme Struktural Ontik adalah pandangan bahwa dunia mempunyai struktur objektif yang tidak bertopang di atas sifat-sifat hakiki himpunan individu. Menurut RSO, bahkan identitas dan individualitas objek bergantung ke struktur relasional dunia" [James Ladyman and Don Ross, "Ontic Structural Realism and the Philosophy of Physics," in Everything must Go: Metaphysics Naturalized, ed. Ladyman and Ross (Oxford: Oxford University Press, 2007), p. 130].

7 Tolok ukur yang cukup membantu untuk menentukan teori-teori terbaik atau kerap disebut sebagai teori yang sudah matang atau teori yang berhasil adalah derajat 
beri penjelasan yang mendekati kebenaran dan/atau boleh jadi benar. Teori-teori terbaik memerikan aspek alam yang dikaji hingga ke derajat yang kian lama kian sesuai dengan wujud, struktur, proses maupun mekanisme alam yang melampaui tataran empiris. Di tataran ontologis, realisme menegaskan ada alam yang terlepas dari andaian dan praktikpraktik epistemik. Pandangan realis bahwa tujuan ilmu adalah memberi pernyataan yang benar mengenai dunia perlu ditempatkan sebagai pernyataan normatif. Kapan kebenaran itu akan tercapai adalah perkara lain. Pandangan itu tidak menyangkal bahwa teori bisa salah. Kebenaran keilmuan dalam tulisan ini berpegang ke pengertian tersebut. Komitmen ontologis realis juga tidak bermaksud mengatakan bahwa teori adalah pantulan utuh dari realitas. Anti-realisme secara sederhana penulis letakkan sebagai posisi filosofis yang menolak posisi-posisi di atas. ${ }^{8}$

ketepatan teori dalam memerikan aspek realitas yang diselidiki, daya ramal serta ketahanan terhadap rangkaian pengujian empiris dalam rentang waktu yang relatif panjang. Tolok ukur ini bersifat perbandingan sehingga teori B lebih baik dari pada teori A jika teori B memenuhi tolok ukur di atas lebih dari pada B dan B tidak saja dapat menjelaskan/meramalkan gejala yang juga dijelaskan/diramalkan oleh teori $\mathrm{A}$ tetapi dapat menjelaskan/meramalkan gejala yang tidak terjelaskan oleh A. Ungkapan "mendekati kebenaran" dapat dipahami secara intuitif maupun formal seperti diberikan oleh Karl Popper dalam Conjectures and Refutations (New York: Basic Books, 2002 [1962]), pp. 231-236 dan Ilkka Niiniluoto, "Verisimilitude: The Third Period," British Journal for the Philosophy of Science 49 (1998): 1-29.

8 Secara umum, realisme keilmuan dapat ditaruh pada tiga sumbu. Pertama, realisme ontologis adalah komitmen terhadap realitas mandiri yang tidak bergantung ke akal budi atau kegiatan epistemik. Kedua, realisme epistemologis adalah komitmen untuk memperlakukan pernyataan-pernyataan teoretis dalam ilmu-ilmu yang ber- hasil sebagai unsur-unsur yang membangun pengetahuan tentang dunia. Bagi realis epistemologis, alasan untuk menerima bahwa sebuah teori (mendekati) kebenaran tidak dapat dipisahkan dari alasan untuk percaya bahwa teori itu (mendekati) benar. Ketiga, realisme semantik adalah komitmen untuk menafsirkan pernyataan-pernyataan mengenai wujud, proses, sifat, dan interaksi yang diteliti ilmu sebagai pernyataan yang memiliki nilai kebenaran (benar atau salah). Ungkapan-ungkapan teoretis mengenai wujud/mekanisme/proses yang takkasat indera diperlakukan sebagai ungkapan yang mempunyai acuan yang nyata. Anti-realisme dalam filsafat ilmu dapat menolak ketiganya, menolak salah satu atau variasi gabungan pertama sampai dengan ketiga. Bentuk paling ekstrim dari anti-realisme keilmuan tidak berasal dari filsafat ilmu tetapi dari sosiologi pengetahuan keilmuan (sociology of scientific knowledge; SSK). SSK memandang ilmu sepenuhnya sebagai konstruksi sosial dan menilai pernyataan-pernyataan keilmuan sebagai konstruksi tekstual berdasarkan kesepakatan subjektif nonrasional para ilmuwan. Tulisan ini tidak membahas versi SSK [program SSK dapat dilihat dalam Sismondo Sergio, "Science and Technology 
Catatan kedua menyangkut istilah wujud atau objek takkasat indera atau takteramati. Naga Besukih, seandainya ada, adalah makhluk yang teramati. Angka 29 tidak teramati tetapi kita memakainya untuk menghitung benda-benda teramati. Dalam fisika, massa bukan wujud yang teramati tetapi astronom dapat menghitung massa planet dari pengaruh gravitasinya terhadap benda langit lain. Dengan kata lain, takteramati bukan berarti tidak terlacak. Kita tidak dapat melihat angin tetapi menyimpulkan ada angin dengan mengamati gerak dedaunan. Para fisikawan yang mengumumkan penemuan boson Higgs tidak pernah melihat zarah itu tetapi mereka melacak jejaknya dalam peluruhan zarah dan ternyata sesuai dengan model teoretis Peter Higgs. Sedang istilah "wujud teoretis" mengacu ke peluang untuk terealisasi atau tidak terealisasi dalam eksperimen/observasi. Eter adalah wujud hipotetis yang menjadi pegangan ilmuwan abad ke-19 tetapi tidak menemukan realisasinya dalam eksperimen. Demikian juga flogiston. Tidak jarang ilmuwan juga memperlakukan wujud teoretis sebagai wujud abstrak matematis untuk membangun tilikan atas struktur realitas yang sedang ia pelajari, atau untuk mengarahkan penelitian ke tahap selanjutnya. Dalam hal ini mereka tidak mempermasalahkan apakah wujud itu mempunyai pasangan real atau tidak.

\section{Meta-Induksi Pesimistik}

Bagi realis, "belief in truth matters." ${ }^{9}$ Kalau kembali ke pernyataan Putnam di atas, ada tiga pernyataan realis di belakang NMA yang terkait dengan pengacuan ke wujud nyata. Pertama, ungkapan-ungkapan dalam teori-teori yang matang umumnya mengacu ke wujud yang nyata. Kedua, teori-teori yang diterima dalam suatu cabang ilmu yang matang biasanya mendekati kebenaran. Ketiga, ungkapan yang sama dapat mengacu ke hal yang sama meskipun muncul dalam teori-teori yang berlainan. Putnam tidak memandang ketiga pernyataan itu sebagai kebe-

Studies and an Engaged Program," in The Handbook of Technology and Science Studies, ed. Edward J. Hackett, et al. (Cambridge, Mass.: MIT Press, 2008), pp. 13-32].

9 Stathis Psillos, "Agnostic Empiricism versus Scientific Realism: Belief in Truth Matters," International Studies in the Philosophy of Science 14 (2000): 57. 
naran mutlak. Ia menyebutnya sebagai bagian dari penjelasan tentang kesuksesan ilmu dan karena itu merupakan pemerian yang memadai tentang ilmu dan relasi ilmu ke objek-objek kajiannya. ${ }^{10}$

Untuk menunjukkan betapa rapuh realisme yang bertopang ke pengacuan, Laudan merumuskan kembali argumen realis mengenai pengacuan ke dalam empat premis, ${ }^{11}$ yaitu (1) Teori-teori dalam bidang ilmu yang matang adalah teori yang berhasil; (2) Sebuah teori yang ungkapan-ungkapan pokoknya mempunyai acuan yang betul, akan menjadi teori yang berhasil; (3) Jika sebuah teori berhasil, kita dapat menyimpulkan bahwa ungkapan-ungkapan pokok dalam teori itu betulbetul mengacu; dan (4) Semua ungkapan pokok dari teori-teori bidang ilmu yang matang memang mengacu ke wujud yang nyata. Laudan menyebut model realisme di atas sebagai realisme konvergen karena dengan berangkat dari peningkatan keberhasilan ilmu, para realis sampai ke tesis bahwa teori-teori keilmuan mengerucut ke pernyataan yang benar tentang struktur dasar alam. Jika kita perhatikan, realisme model ini berpegang ke konsep pengacuan, pendekatan terhadap kebenaran dan keberhasilan ilmu.

Kendati Laudan melihat hubungan dari (1) sampai dengan (4) cukup rumit, ia memusatkan perhatiannya ke premis (2). Seperti sudah disebut di atas, Laudan memberi contoh bahwa premis itu tidak selalu benar dalam sejarah ilmu. Teori yang mengacu tidak selalu berhasil untuk waktu yang cukup lama dan sebaliknya, teori yang berhasil ternyata acuannya keliru. Hal ini menunjukkan bahwa tidak ada hubungan logis antara kesuksesan teori dan ketepatan pengacuannya. Laudan menyusun daftar yang lumayan panjang berisi teori-teori semacam itu untuk menggoyahkan optimisme Putnam. "Kalau tidak ada sesuatu yang mirip

10 Hilary Putnam, Mathematics, Matter and Method: Philosophical Papers, Vol. 1 (London: Cambridge University Press, 1975), p. 72. Seperti dijelaskan Putnam, tesis pertama mengacu ke Richard Boyd [Richard Boyd, "On The Current Status of Scientific Realism," in The Philosophy of Science, eds. Richard Boyd, Philip Gasper, J. D. Trout (Cambridge, Mass.: MIT Press, 1991), p. 195].

11 Perhatikan (2) dan (4) menjelaskan (1), sementara (1) dan (3) menjamin (4) [Lihat Larry Laudan, "A Confutation," p. 23]. 
dengan gen, tentu teori genetika tidak mungkin mendekati benar," tulis Laudan. ${ }^{12}$

IP bukan tantangan sepele bagi realis. Sampai pertengahan abad ke-20 banyak filosof realis direpotkan oleh argumen underdetermination, ${ }^{13}$ tetapi sejak filsafat ilmu menggunakan orientasi kesejarahan dalam analisisnya IP-lah yang menjadi pusat perhatian mereka. Dengan hati-hati Laudan mengatakan bahwa ia tidak bermaksud menyangkal realisme keilmuan. "Kita semua ingin realisme benar; kita ingin berpikir bahwa ilmu berhasil karena mempunyai cengkeraman atas pelbagai hal sebagaimana adanya ... tetapi ada perbedaan antara ingin mempercayai sesuatu dan mempunyai alasan yang baik untuk mempercayai sesuatu."14

Stathis Psillos mengatasi argumen Laudan dengan merumuskan tolok ukur keberhasilan ilmu secara lebih ketat. Hanya ramalan yang sungguh-sungguh membuahkan hal-hal baru yang dapat diterima sebagai kriteria keberhasilan teori dan teori itu tidak tergolong teori ad hoc. ${ }^{15}$

12 Larry Laudan, “A Confutation," p. 33. IP sebetulnya mirip pendapat Popper: juga seandainya kita merasa tidak dapat lagi meragukan kebenaran sebuah teori, teori itu tetap ber-status hipotesis dan berpeluang untuk dinyatakan salah.

13 Underdetermination of theory by data menegaskan bahwa data saja tidak dapat memastikan apakah teori A benar dan teori B saingannya salah. Tidak ada experimentum crucis model Bacon, atau dalam versi Popper, percobaan yang memfalsifikasi sebuah hipotesis. Sehimpunan data empiris yang sama dapat mendukung beberapa teori dan semua teori itu secara logis ajeg dengan data tersebut padahal teori-teori itu berisi pernyataan yang berbeda-beda mengenai aspek yang sedang diselidiki \{Pierre Duhem menguraikan masalah ini dalam The Aim and Structure of Physical Theory, transl. Philip P. Wiener (Princeton: Princeton University Press, 1954 [1906])\}.

14 Larry Laudan, "A Confutation," p. 48.

15 Psillos memberikan definisi yang umum tentang kategori baru sebuah ramalan, “[s]ebuah ramalan $P$ atas gejala $G$ merupakan sesuatu yang baru relatif terhadap teori $\mathrm{T}$ jika $\mathrm{G}$ diketahui sebelum $\mathrm{T}$ diajukan, $\mathrm{T}$ tidak memenuhi syarat teori ad hoc dan $\mathrm{T}$ meramal G" (ibid., p. 102). Sebuah teori T disebut sebagai teori ad hoc relatif terhadap sebuah gejala $G$ jika dan hanya jika salah satu syarat berikut terpenuhi: (a) ada pengetahuan latar L yang menunjukkan adanya gejala $G$. Informasi mengenai $G$ digunakan untuk membangun teori $T$ dan $T$ sesuai dengan $G$, atau (b) sebuah pengetahuan latar L menunjukkan adanya gejala G. Teori T yang sudah ada tidak meramalkan atau menjelaskan $\mathrm{G}$. T lalu dimodifikasi menjadi $\mathrm{T}^{\prime}$ sehingga $\mathrm{T}^{\prime}$ meramal $\mathrm{G}$ dan satu-satunya alasan untuk memodifikasi $\mathrm{T}$ adalah agar dapat meramalkan/ menjelaskan G. $T^{\prime}$ tidak secara khusus memiliki kandungan teoretis atau empiris yang melebihi T [Stathis Psillos, Scientific Realism: How Science Tracks Truth (London: Routledge, 1999), pp. 99-101; Bdk. Stathis Psillos, "Is the History of Science the Wasteland of False Theories?" in Adapting Historical Knowledge Production to the 
Pembatasan ini mirip anjuran Putnam agar orang bermurah hati dalam menilai teori, namun bukan tanpa syarat. ${ }^{16}$ Dengan tolok ukur itu kita dapat menjelaskan mengapa teori Newton lebih layak diterima dari pada teori flogiston atau teori kalorik. Teori Newton berhasil menjelaskan gejala yang sudah lama diamati (antara lain gerak gasing poros rotasi Bumi, pasang surut air laut) dan meramal gejala yang sepenuhnya baru (penemuan Neptunus menggunakan gangguan pada orbit Uranus). Sedang teori flogiston menjelaskan penambahan massa logam yang berkarat sesudah mengikutsertakan hipotesis tambahan berupa massa negatif flogiston.

Pembatasan Psillos memperpendek daftar Laudan tetapi tidak cukup untuk menyingkirkan IP. Kalau argumen Laudan diterima, konsep pengacuan yang menjadi pegangan ilmu-ilmu empiris akan runtuh dan kalimat-kalimat keilmuan yang mengandung ungkapan teoretis tidak dapat dikenai nilai-kebenaran. Hal ini berarti ilmu, sebaik-baiknya, hanya mencapai taraf memadai secara empiris tetapi tidak dapat menjelaskan mekanisme yang melandasi munculnya gejala amatan. Atau, ilmu sekadar alat hitung berdasarkan kesepakatan ilmuwan. Dengan posisi ini, ilmuwan tidak mempunyai alasan yang kuat untuk mengatakan kepada Apffel-Marglin bahwa vaksinasi lebih aman ketimbang inokulasi.

\section{MENJEMBATANI REALISME DAN ANTI-REALISME}

Orang awam tertegun menyaksikan kelebat gerak teori-teori keilmuan. Ia menyaksikan teori-teori dibuang sesudah menjalani masa subur selama beberapa tahun; ia melihat puing-puing yang semakin bertumpuk; ia meramalkan teori-teori yang hari ini digandrungi dalam waktu dekat akan mendapat giliran, lalu ia menyimpulkan alangkah sia-sianya semua itu. Inilah yang ia namakan kebangkutan ilmu. ${ }^{17}$

Classroom, ed. P. V. Kokkotas, K. S. Malamitsa, and A. A. Rizaki (Rotterdam: Sense Publishers, 2011), pp. 17-36.

16 Hilary Putnam, Meaning and the Moral Sciences, pp. 23-25.

17 Henri Poincaré, "Science and Hypotheses," in The Foundations of Science, trans. George Bruce Halsted (New York: The Science Press, 1913 [1903]), p. 140. Posisi epistemik 
Kalimat Henri Poincaré di atas menggambarkan secara dramatik pesimisme Laudan. Ernst Cassirer mengemukakan hal yang sama. Syukurlah, kata Cassirer, ilmu telah melepas tujuan untuk mendapatkan salinan utuh realitas. Sebagai seorang neo-Kantian, Cassirer memahami ilmu sebagai upaya untuk "menelusuri skema intelektual universal yang dapat mengemukakan dengan sempurna relasi-relasi dan tautan-tautan persepsi ... atom, eter, massa dan gaya hanyalah contoh-contoh dari skema seperti itu." 18 Bagi Cassirer ilmu-ilmu kealaman mengalami kemajuan karena memusatkan perhatiannya ke relasi-relasi dan mengemukakan realitas sebagai tautan keniscayaan antara penyebab dan konsekuensinya.

RSE memberi nafas baru bagi gagasan di atas dengan mengakomodasi pemikiran Poincaré yang memilah teori menjadi dua bagian, yaitu komponen faktual dan komponen formal. Bagi Poincaré komponen formal berisi hasil kesepakatan sedang komponen faktual mengemukakan relasi-relasi $(R)$ kongkret di antara objek-objek nyata dalam alam. $R$ terejawantahkan ke dalam hukum-hukum fisika yang dapat dirumuskan secara matematis. Konsep-konsep teoretis seperti eter, elektron, gravitasi, dan lain-lainnya, dalam penafsiran Poincaré sekadar "nama pengganti" un-tuk wujud-wujud nyata yang "selama-lamanya disembunyikan oleh alam." ${ }^{19}$ Dengan penafsiran ini, pemilihan "nama" yang salah tidak akan mempengaruhi kemampuan teori meramalkan gejala. Poincaré mengambil contoh teori optik Fresnel. Teori itu dapat meramal gejala optik dengan tepat padahal bertopang di atas andaian cahaya sebagai sejenis

Poincaré pernah penulis bahas sehingga ada bagian yang menunjukkan kemiripan (Karlina Supelli, "Ilmuwan dan Problem Epistemik Ruangwaktu," Diskursus 4 (April 2005): 19-27.

18 Ernst Cassirer, Substance and Function and Einstein's Theory of Relativity (Chicago: The Open Court Publishing Company, 1923), pp. 164-165.

19 Hendri Poincaré, "Science and Hypotheses," pp. 140-141. Realisme struktural Poincaré tidak dapat langsung digolongkan sebagai RSE. Di tataran epistemik, Poincaré bukan realis melainkan konvensionalis. Strukturalisme ia bangun di atas konsep-konsep a priori Kantian. Realismenya terletak di aras ontologis dan mengikuti pemilahan Kant atas noumena dan fenomena. Untuk kepentingan pembahasan RSE kerumitan ini penulis abaikan. Tentang konvensionalisme Poincaré, lihat Elie Zahar, Poincaré's Philosophy: From Conventionalism to Phenomenology (Chicago: Open Court, 2001). 
gangguan pada medium eter. Ketika teori elektromagnetik Maxwell menggantikan teori Fresnel, konsep eter tidak lagi diperlukan tetapi persamaan Fresnel terangkut secara utuh ke teori Maxwell. Bagi Poincaré hal itu merupakan tanda bahwa persamaan Fresnel berhasil mengemukakan relasi-relasi nyata sehingga tidak hilang dalam teori baru yang lebih baik.

John Worrall dan Elie Zahar melihat gagasan Poincaré merupakan sarana yang ampuh untuk menanggapi IP. Mengikut Poincaré, Worrall menulis, "[ada] kesinambungan atau penumpukan dalam pergeseran teori, tetapi kesinambungan itu berupa bentuk atau struktur, bukan isi." 20 Struktur inilah yang membangun landasan ilmu. Struktur berisi prinsipprinsip dasar fisika yang tidak berubah. Ketika teori berganti, struktur yang mengemuka dalam teori lama akan muncul lagi dalam teori yang baru, baik secara utuh ataupun sebagian. Dengan pertimbangan ini RSE menaruh komitmen epistemiknya di struktur teori dan bukan di wujudwujud alami takteramati yang dipostulatkan oleh teori. Para filosof RSE berpendapat bahwa ilmu tidak mempunyai jangkauan epistemik ke hakikat wujud-wujud itu tetapi dapat menunjukkan bahwa wujud itu ada melalui struktur yang terbangun dari relasi-relasi di antara wujud-wujud itu.

Dari uraian ringkas di atas terlihat bahwa RSE menerima sebagian model revolusi keilmuan Kuhn tetapi masih dapat mendukung NMA. Perubahan radikal yang terjadi dalam pergantian teori hanya menyangkut komponen ontologis, sedang komponen strukturalnya tidak terputus. Komponen struktural merepresentasikan struktur alam dan kemunculannya secara ajeg dalam teori-teori berbeda merupakan penanda

20 John Worrall, “Structural Realism: The Best of Both Worlds,” Dialectica 43 (1989): 117. Cetak miring dari Worrall [artikel ini diterbitkan kembali dalam David Papineau, The Philosophy of Science (London: Oxford University Press, 1996)]. Lihat juga Worrall, "Miracles and Models: Why reports of the death of Structural Realism may be exaggerated," Philosophy of Science, ed. Anthony O'Hear, Royal Institute of Philosophy Supplement, Vol. 61 (October 2007), p. 142. Kajian Worrall tentang Poincaré dan Duhem terdapat dalam Worrall, "Scientific Realism and Scientific Change," The Philosophical Quarterly 32. Special Issue: Scientific Realism (Jul. 1982), pp. 201-231. 
bahwa teori bergerak mendekati kebenaran. Dengan memilah fungsi epistemik antara struktur dan wujud RSE dapat menjelaskan kesuksesan teori melampaui aras empiris tanpa terpukul mundur oleh fakta sejarah ilmu. Pemilahan ini pula yang membedakan RSE dari realisme tradisional dan sekaligus dari anti-realisme. Dengan menerima IP-minus-pesimismenya, RSE dapat mengatakan bahwa tidak betul teori pada akhirnya akan selalu dinyatakan salah. Para pendukung RSE percaya, inilah posisi terbaik di antara realisme dan anti-realisme, the best of both worlds.

Untuk memahami argumen RSE, bayangkanlah sebuah teori T yang memerikan atom sebagai kubus. Beberapa waktu kemudian muncul T' yang menyatakan atom sebagai oktahedron. Dengan bukti-bukti empiris yang kuat antirealis akan menyatakan bahwa T salah. Namun RSE akan mengatakan bahwa komponen struktural $\mathrm{T}$ benar karena kedua bentuk itu mempunyai grup kesetangkupan yang sama melalui perputaran/ pencerminan pada sumbu tertentu. Ringkasan posisi RSE terlihat cukup gamblang dalam perumusan Stathis Psillos. ${ }^{21}$ Pertama, teori-teori keilmuan hanya dapat menyingkap bentuk logis atau struktur realitas fisis melalui struktur matematisnya. Kedua, persamaan matematis yang bertahan dalam pergantian teori mengemukakan relasi-relasi nyata di antara objek-objek tetapi objek-objek itu tidak dapat diketahui kecuali bahwa objek-objek ada di antara relasi-relasi itu. Ketiga, ontologi yang berbeda dapat memenuhi struktur matematika yang sama tetapi tidak ada alasan tersendiri untuk percaya bahwa salah satu di antaranya merupakan ontologi yang tepat.

\section{STRUKTUR TEORI DAN STRUKTUR REALITAS}

Apakah yang dimaksud dengan struktur teori? Ilmuwan mengacu ke struktur kongkret seperti struktur molekul, struktur DNA, struktur Bumi atau struktur atom Bohr. Struktur juga dapat berupa struktur abstrak matematis yang dinyatakan sebagai sebuah himpunan $S$ berang-

21 Psillos menyusun rumusan ini untuk mengkritik RSE [Stathis Psillos, "Is Structuralism the Best Possible Worls?" Dialectica 49 (1995): 21, 23]. Bdk. Stathis Psillos, Knowing the Structure of Nature (New York: Palgrave, MacMillan, 2009). 
gotakan wujud-wujud abstrak dengan relasi-relasi $R_{1}, R_{2} \ldots$ Worrall tidak secara khusus mendefinisikan struktur teori yang ia maksudkan. Baru kemudian ia menggunakan metode matematikawan Frank Ramsey yang pernah dipakai oleh Grover Maxwell untuk menghidupkan lagi RS Bertrand Russell. Dalam pendapat Maxwell, metode Ramsey dapat mengungkap struktur teori secara optimal dan memeras isi kognitif ungkapanungkapan teoretis di dalamnya. ${ }^{22}$

Metode Ramsey memilah teori ke dalam ungkapan teoretis (ungkapan-T) dan predikat observasional (ungkapan-O). Ungkapan-T merupakan ungkapan tatanan-pertama (first-order) yang berisi pernyataan tentang objek-objek partikular. Ungkapan-T sepenuhnya berisi kosa kata empiris atau ungkapan yang sudah diketahui dari penemuan sebelumnya. Dengan demikian, makna ungkapan-O berasal dari luar teori. Dalam bahasa formal, sebuah teori ditulis sebagai $\mathrm{T}\left(t_{1}, \ldots, t_{\mathrm{n}^{\prime}} ; o_{1}, \ldots, o_{\mathrm{m}}\right)$ dengan $\left(t_{1}\right.$ $\left.t_{2}, \ldots t_{\mathrm{n}}\right)$ adalah predikat teoretis dan $\left(o_{1}, o_{2}, \ldots o_{\mathrm{m}}\right)$ merupakan predikat observasional. Dalam kenyataan, ungkapan-T tidak selalu dapat sepenuhnya dirumuskan ke dalam kosa kata observasional. Bila ungkapan teoretis tidak terumuskan dalam kosa kata yang menghubungkannya ke pengalaman empiris, atas dasar apa kita mengatakan wujud yang dipostulatkan betul ada dan mempunyai sifat seperti yang dikemukakan oleh teori?

Ramsey menjawab pertanyaan itu dengan menunjukkan bahwa ungkapan teoretis sebetulnya merupakan pemerian takrif terselubung (disguised definite description) sehingga kita dapat membangun $\mathrm{T}^{\prime}$ yang secara fungsional sepadan dengan $\mathrm{T}$, tetapi sepenuhnya menggunakan ungkapan-ungkapan observasional tanpa melenyapkan ontologi yang mau dikemukakan oleh T. Sepadan secara fungsional berarti $\mathrm{T}^{\prime}$ memiliki daya penjelasan dan daya peramalan yang sama dengan $T$. Langkah pertama Ramsey adalah mengganti setiap ungkapan-T yang merupakan ungkapan tatanan-pertama ke peubah tatanan-kedua (second-order) $X_{i}$ lalu mengikatnya ke kuantor eksistensial $\exists$ sesuai jumlahnya. Hasilnya

22 Grover Maxwell, "Structural Realism and the Meaning of Theoretical Terms," Minnesota Studies in the Philosophy of Science 4 (1971): 181-192. 
adalah kalimat-Ramsey $\left({ }^{\mathrm{R}} \mathrm{T}\right): \exists X_{1} \ldots \exists \mathrm{X}_{m} \mathrm{~T}\left(\mathrm{X}_{1} \ldots X_{m^{\prime}} \mathrm{O}_{1} \ldots, \mathrm{O}_{n}\right)$. Secara

logis ${ }^{\mathrm{R}} \mathrm{T}$ tidak sepadan dengan $\mathrm{T}$, tetapi ${ }^{\mathrm{R}} \mathrm{T}$ merupakan implikasi logis dari T. Kalimat-Ramsey ${ }^{\mathrm{R}} \mathrm{T}$ tidak lagi mengandung corak khusus yang mengacu ke wujud tertentu tetapi hanya mengatakan ada serangkaian sesuatu dengan sifat-sifat serta relasi-relasi bercorak logis sebagaimana dinyatakan oleh $\mathrm{T}$, dan sesuatu itu terhubungkan ke wujud observasional $O_{i}$. Peubah yang terkuantifikasi mengangkut semua komitmen ontologis $\mathrm{T}$ tetapi meniadakan masalah interpretasi filosofisnya.

Ambil contoh sebuah teori yang mengandung ungkapan elektron, kecepatan, dan massa. Sesudah kita mengganti ungkapan-ungkapan itu dengan peubah $X_{1}, Y_{1}, Z_{1}$ lalu mengikatnya ke kuantor eksistensial, kita mendapat kalimat-Ramsey ${ }^{\mathrm{R}} \mathrm{T}$ yang mengatakan ada sesuatu, $X_{1}$ dalam kawasan tertentu dunia dan sesuatu itu memenuhi dua syarat. Pertama, semua hal mengenai $X_{1}$ terutarakan dalam ungkapan observasional. Kedua, sesuatu itu ada dalam kawasan dunia yang juga memenuhi relasi-relasi dengan sesuatu yang lain, $Y_{1}$ dan $Z_{1}$ yang dipostulatkan oleh teori. ${ }^{\mathrm{R}} \mathrm{T}$ tidak lagi mengandung sifat-sifat wujud tertentu karena kalimat "massa elektron $=5$ " terumuskan ke dalam pemerian struktural, "ada suatu $X_{1}$ dan suatu $Z_{1}$ sedemikian sehingga $Z_{1}\left(X_{1}\right)=5$."

Dalam ${ }^{\mathrm{R}} \mathrm{T}$, peubah $X_{i}$ dapat berisi apa saja tanpa mempengaruhi

struktur logis $\mathrm{T}$, sementara hubungannya ke kawasan empiris terjamin. Karena ${ }^{\mathrm{R}} \mathrm{T}$ merupakan konsekuensi deduktif dari teori $\mathrm{T}$ dalam logika tatanan-kedua, ${ }^{\mathrm{R}} \mathrm{T}$ tidak lebih kuat dari pada T. ${ }^{\mathrm{R}} \mathrm{T}$ benar jika dan hanya jika kalimat $\mathrm{T}$ benar. ${ }^{\mathrm{R}} \mathrm{T}$ juga merupakan perampatan eksistensial dari $\mathrm{T}$ sehingga setiap konsekuensi observasional dari ${ }^{\mathrm{R}} \mathrm{T}$ merupakan konsekuensi dari T. Seandainya ungkapan teoretis dalam T adalah "Kuda Bersayap" atau "Naga Besukih," kita dapatkan bahwa ${ }^{\mathrm{R} T}$ bagi teori itu salah karena kedua syarat yang disebut di atas tidak terpenuhi. ${ }^{\mathrm{R}} \mathrm{T}$ tidak bisa benar jika teori yang menurunkannya tidak sesuai dengan fakta observasi. ${ }^{23}$

23 Contoh lain misalnya ada sebuah teori mengenai unsur radioatif radium yang mengatakan jika atom meluruh, akan terlacak melalui alat cacah Geiger. Dalam logika tatanan-pertama $\mathrm{T}=\forall x \forall y[(A x \& D x \rightarrow \exists y(C y)]$ dengan $A$ dan $D$ berturut-turut adalah predikat teoretis untuk "adalah atom radium" dan "adalah meluruh dalam 
Kalimat-Ramsey membebaskan RSE dari pengetahuan tentang wujud tetapi masih dapat mengatakan bahwa wujud itu ada bersama relasi-relasinya, dan baik wujud maupun relasi-relasinya tercantum dalam struktur gejala teramati. Pendukung RSE percaya bahwa ${ }^{R} T$ mengangkut semua kandungan kognitif $\mathrm{T} .{ }^{24}$ Ini berarti ${ }^{\mathrm{R}} \mathrm{T}$ tidak saja menangkap kandungan empiris teori, tetapi memiliki kesepadanan penuh dengan aspek realitas yang dimaksudkan oleh teori berdasarkan isomorfisme. Dengan menggunakan metode Ramsey, posisi epistemik RSE mengemuka dengan lebih tegas dalam dua komponen, yaitu (1) persamaan matematis dalam teori yang mewakili struktur realitas yang menjadi target kajiannya dan (2) bagian non-struktural teori yang menyatakan adanya wujudwujud pembangun struktur tetapi hakikatnya tidak dapat diketahui.

\section{MASALAH REALISASI JAMAK}

Marilah kita bayangkan sebuah kawasan dunia yang berisi bendabenda sejumlahê (ê disebut bilangan kardinal) dengan sistem relasi $R$ di antaranya. Tugas kita adalah membangun struktur $S$ bagi kawasan itu. Kita tidak mempunyai pengetahuan apa-apa tentang benda-benda dan tentang $R$ kecuali ada $R$ dan ada gugus benda. Ternyata kita dapat membangun struktur apa saja bagi kawasan itu asalkan sesuai dengannya. Andaikan kita mempunyai batang-batang baja pelbagai ukuran dan sejumlah beton. Kita dapat menyusun bahan-bahan itu menjadi jembatan Ampera (Palembang) atau jembatan Siak (Pekanbaru) asalkan jumlah komponen keduanya sama. Inilah masalah yang muncul pertama kali dalam kritik matematikawan Max Newman atas RS Russell. Newman menunjukkan bahwa pernyataan "ada sebuah sistem relasi

proses radioaktif," serta $C$ menunjuk ke predikat observasi untuk "pencatatan oleh alat cacah Geiger." Kalimat-Ramsey bagi T adalah RT $=\exists \psi \exists \partial \forall x \forall y[(\psi x \& \ddot{\partial} x \rightarrow$ $\exists y(O y)]$ yang mengatakan ada wujud takteramati $\psi$ dan $\ddot{o}$ sedemikian rupa sehingga jika kedua-duanya terjadi maka alat cacah Geiger akan berbunyi. Kendati kita tidak mempunyai pengetahuan tentang ungkapan-ungkapan dalam kalimat $\mathrm{T}$, kita tahu bahwa wujud yang dipostulatkan dan relasi yang terkait dengan wujud itu ada (penjelasan rinci tentang metode Ramsey dan contoh ini dapat dilihat dalam Maxwell, "Structural Realism," pp. 185-186).

24 John Worrall, "Miracles and Models," p. 147. 
yang terdefinisikan untuk kawasan $\mathrm{K}$ dengan struktur $S^{\prime \prime}$ tidak memadai untuk menghasilkan pengetahuan yang unik tentang dunia. Struktur $S$ dapat diganti oleh $S^{\prime}, S^{\prime \prime}, S^{\prime \prime}$ dan seterusnya yang cocok untuk kardinalitas kawasan $\kappa$. Untuk memperoleh struktur yang unik kita memerlukan informasi tambahan mengenai $R$. Akan tetapi, karena informasi itu tidak terkandung dalam unsur-unsur struktural, RS terpaksa mencarinya dari komponen non-struktural. Bukankah ini berarti RS tidak lagi murni bersifat struktural? ${ }^{25}$

Keberatan Newman muncul lagi dalam kritik Demopoulos dan Friedman terhadap RSE Maxwell-Russell. Keberatan Newman selanjutnya menjadi semacam konsensus untuk menolak argumen RSE bahwa ${ }^{\mathrm{R}} \mathrm{T}$ menangkap sepenuhnya kandungan kognitif T. Kita ingat bahwa argumen RSE adalah jika ${ }^{\mathrm{R}} \mathrm{T}$ benar, kita akan mendapatkan pengetahuan mengenai struktur kawasan fisis yang sesuai dengan struktur teori. Para pengkritik RSE melihat bahwa pendekatan Ramsey dalam RSE mengakibatkan RSE terkena problem Newman karena kuantifikasi eksistensial mengalihkan semua predikat teoretis ke pernyataan ada relasi dan ada wujud-wujud. Demopoulos-Friedman dan kemudian Ketland menunjukkan bahwa jika T ajeg dan mempunyai model yang tepat secara empiris (berarti semua konsekuensi observasionalnya benar), ${ }^{\mathrm{R}} \mathrm{T}$ niscaya benar. Akibatnya, penegasan bahwa ada elektron, ada quark, dan sebagainya menjadi penegasan a priori dalam batas kardinalitasnya. ${ }^{26}$ Satu-satunya kelebihan yang dapat diberikan oleh kebenaran ${ }^{\mathrm{R}} \mathrm{T}$ yang melampaui

25 M.H.A. Newman, "Mr. Russell's "Causal Theory of Perception," Mind, New Series 37 (April 1928): 140-144, 147.

26 William Demopoulos and M. Friedman, "Critical Notice: Bertrand Russell's The Analysis of Matter: Its Historical Context and Contemporary Interest," Philosophy of Science 52 (1985): 635. Hampir semua kritik terhadap RSE mengangkat keberatan Newman [lihat James Ladyman and Don Ross, "Ontic Structural Realism," pp. 125128; bdk. Psillos, "Carnap, The Ramsey-Sentence," Erkenntnis 52 (2000): 270-275; bdk. Steven French and Juha Saatsi, "Realism about Structure: The Semantic View and Non-linguistic Representations," Philosophy of Science 73 No. 5, Proceedings of the 2004 Biennial Meeting of The Philosophy of Science Association Part II: Symposia Papers (December 2006), p. 550]. Sanggahan Worrall dan Zahar dapat dilihat dalam Zahar (2001) dan Worrall (2007). 
pernyataan tentang kardina-

litas adalah teori memadai se-

cara empiris. ${ }^{27}$ Padahal realisme

mau melampaui pernyataan

kebenaran yang terletak di aras empiris.

Banyak pengkritik RSE juga mengutip Jane English yang menunjukkan bahwa dua kalimat-Ramsey dengan konse-

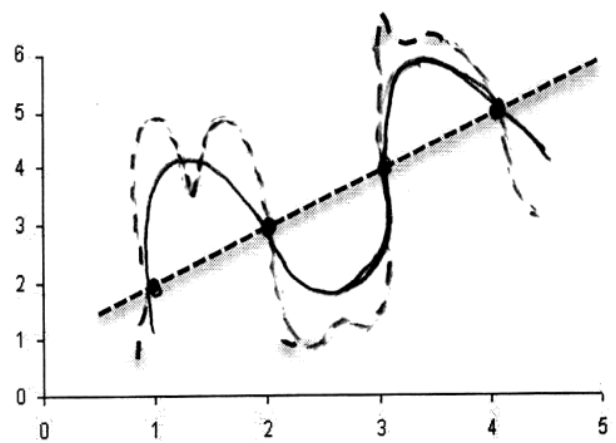

Gambar 1. Ada tiga model kurva yang semuanya memenuhi distribusi ke-4 titik di atas, yaitu kurva linier, kurva parabolik, dan kurva non-linier

kuensi observasional yang sa-

ma, tidak dapat tidak, akan ajeg

satu sama lain. Padahal dapat saja kedua kalimat itu menggambarkan realitas yang berbeda atau bahkan bertolak-belakang sebelum menjalani Ramseyfikasi. ${ }^{28}$ Kendati tidak terlalu tepat, gambar 1 melukiskan persoalan realisasi jamak yang dimunculkan English. Kita lihat distribusi keempat titik dalam gambar 1 sesuai bagi fungsi matematis yang berlainan. Manakah fungsi (baca: teori) yang merupakan representasi terbaik

27 Ketland mengembangkan kritik Demopoulos-Friedman dan membuktikan bahwa kebenaran ${ }^{\mathrm{R}} \mathrm{T}$ tentang struktur $S$ yang memenuhi teori $\mathrm{T}$ ternyata melahirkan dua konsekuensi (a) teori $\mathrm{T}$ memiliki model $\mathrm{M}$ yang sepenuhnya tepat secara empiris, dan (b) model itu memiliki kardinalitas yang tepat. Ini berarti satu-satunya kelebihan RSE (sejauh diidentifikasikan dengan ${ }^{\mathrm{R}} \mathrm{T}$ ) dari empirisisme konstruktif adalah kandungan strukturalnya, yaitu pengetahuan tentang kardinalitas [Jeffrey Ketland, "Empirical Adequacy and Ramsification," The British Journal for the Philosophy of Science 55 (June 2004): 298-299].

28 Simak dua pernyataan dengan dua konsekuensi teoretis yang saling bertentangan: $(x)(P x) \&(x)(P x \rightarrow O x)$ dan $(x)(\neg P x) \&(x)(\neg P x \rightarrow O x)$ dengan $P$ adalah predikat teoretis dan $O$ predikat observasional. Kalimat-Ramsey bagi kedua pernyataan itu berturutturut adalah $(\exists \ddot{o})[(x)(\ddot{o} x) \&(x)(\ddot{o} x \rightarrow O x)]$ dan $(\exists \psi)[(x)(\neg \psi x) \&(x)(\neg \psi x \rightarrow O x)]$. Tampak kedua teori yang saling bertentangan itu memiliki kalimat Ramsey yang sepadan. Tidak ada yang bisa menghalangi $\neg \psi \equiv \ddot{o}$ [(Jane English, "Underdetermination: Craig and Ramsey," Journal of Philosophy 70 (1973): 458]. Dalam bentuk yang sederhana, kalimat "Ani, Ina dan Adi ada di kebun" dan pernyataan eksitensialnya "Ada seorang perempuan beruban bersama Adi di kebun" adalah benar, tetapi bisa merupakan perampatan eksistensial dari "Ani adalah perempuan beruban bersama Adi di kebun" atau "Ina adalah perempuan beruban bersama Adi di kebun." Padahal, hanya ada satu pernyataan yang benar. 
dari aspek realitas yang sedang dipelajari? Kita tidak dapat menjawab pertanyaan itu dengan hanya berpegang ke pengetahuan struktural.

Para pengkritik RSE juga menilai RSE-plus-Ramseyfikasi menjadikan kebenaran teori terlalu sepele dan kurus. Jika ada cukup banyak objek dalam alam semesta, kalimat-Ramsey akan selalu benar. Hempel sudah jauh lebih dulu mengemukakan ketidakpuasannya terhadap Ramseyfikasi, kendati ia sepakat dengan kemampuan metode Ramsey untuk menunjukkan corak logis teori. Akan tetapi, dengan menghindari pengacuan ke wujud kalimat-Ramsey tidak menyediakan jaminan yang lebih kuat dari pada yang sudah disediakan oleh teori, yaitu bahwa wujudwujud teoretis dapat dihubungkan ke ungkapan observasi dan dapat dinyatakan ada. Padahal dalam kegiatan keilmuan, demikian Hempel menjelaskan, ketika ilmuwan menyatakan bahwa zarah-zarah elementer yang dikemukakan oleh teori ada secara faktual karena memperlihatkan gejala eksperimen yang sesuai, mereka mau menegaskan nilai kebenaran (salah/benar) interpretasi teori fisika zarah. Bagi Hempel, Ramseyfikasi menimbulkan kehilangan yang serius dalam ilmu. Ilmu perlu bisa mengatakan bahwa penjelasannya tentang wujud benar atau salah, dan bukan sekadar mengajukan pernyataan eksistensial. ${ }^{29}$

\section{TANGGAPAN RSE}

Dari uraian sejauh ini tampak bahwa RSE perlu menyediakan jalan keluar bagi masalah (a) realisasi jamak dan menunjukkan kehandalan historis teori agar (b) dapat mendukung NMA dan menanggapi IP. Worrall dan Zahar mengajukan dua jalan keluar heuristik. Jalan pertama adalah pertimbangan, sebut saja, derajat kesuburan teori. Misalnya ada

29 Carl Hempel, "The Theoretician's Dilemma: A study in the logic of theory construction," in Minnesota Studies in the Philosophy of Science, eds. H. Feigl, M. Scriven and G. Maxwell, Vol. 2 (Minneapolis: University of Minnesota Press, 1958), pp. 85, 87. Ada pelbagai upaya untuk mengembangkan metode Ramsey, antara lain oleh Carnap (1966) dan Lewis (1970). Upaya kontemporer berjalan melalui program Canberra Plan yang memperluas penggunaan kalimat-Ramsey untuk menganalisis konsepkonsep di luar ilmu-ilmu empiris seperti dalam filsafat dan sosiologi [lihat David Braddon-Mitchell and Robert Nola, eds., Conceptual Analysis and Philosophical Naturalism (Cambridge, Massachusetts: MIT Press, 2009). 
$T_{1}$ dan $T_{2}$. Ilmuwan akan memilih $T_{2}$ kalau struktur matematis $T_{2}$ berpeluang lebih besar bagi pengembangan teori baru $\mathrm{T}_{3}$ yang lebih baik dari pada $\mathrm{T}_{1}$ maupun $\mathrm{T}_{2}$. Pertimbangan ini tidak dapat secara epistemik membedakan ${ }^{\mathrm{R} T}$ dari T-nya, ${ }^{30}$ tetapi (a) dapat terjawab dan (b) terpenuhi jika ada struktur $T_{2}$ yang terbawa ke $T_{3}$.

Jalan kedua adalah memanfaatkan prinsip metafisis ketika terjadi (a). Zahar mengambil contoh Einstein yang mengandaikan alam semesta sebagai penjelmaan dari hal-hal yang ratah secara matematis. Sedang Poincaré berpegang ke derajat keterpaduan sekaligus keratahan hipotesis sebagai penanda teori mendekati kebenaran. ${ }^{31}$ Ilmuwan memang memanfaatkan keunggulan non-empiris atau pertimbangan estetik seperti keratahan, kesetangkupan, ekonomi, dan keterpaduan teori untuk membatasi jumlah solusi yang berterima seperti dalam kasus realisasi jamak. Masalahnya, belum ada kriteria epistemologis yang dapat menghubungkan kriteria estetik ke kriteria kebenaran. Penggunaan kelebihan estetik teori untuk mengatasi realisasi jamak berisiko membawa RSE ke argumen kebenaran epistemik berdasarkan intuisi a priori bahwa teori yang indah adalah teori yang benar. ${ }^{32}$

Pendukung RSE juga menolak keberatan Newman. Berbeda dengan RSE, Newman tidak membedakan antara predikat observasional dan

30 Zahar dan Worrall membandingkan struktur matematis Dinamika Newtonian $\left(\mathrm{T}_{1}\right)$ dengan Dinamika Hamiltonian Klasik $\left(\mathrm{T}_{2}\right)$. Struktur keduanya berbeda tetapi memiliki kesepadanan observasional yang ketat. Ketika $T_{2}$ berkembang menuju Mekanika Kuantum (S) hanya struktur matematika $\mathrm{T}_{2}$ dalam bentuk fungsi Hamilton yang bertahan, tetapi tipe logisnya mengalami perubahan. Fungsi Hamilton klasik $\mathrm{H}$ berisi pernyataan tatanan-kesatu berupa posisi, waktu dan momentum, sedang dalam $\mathrm{S}$ fungsi itu muncul sebagai pengandar (operator) Hamilton $\hat{H}$ tatanan-kedua. $\mathrm{H}$ dan $\hat{\mathrm{H}}$ sama-sama menyatakan energi tetapi bagi sistem yang berbeda.

31 Zahar and Worrall, Poincaré's Philosophy, p. 249. Einstein menggunakan kriteria keratahan sehingga teori relativitas khusus melampaui program klasik program klasik Lorentz-Poincaré (Elie Zahar, "Why Did Einstein's Programme Supersede Lorentz's? (I)," The British Journal for the Philosophy of Science 24 (June, 1973): 116. Untuk membatasi jumlah solusi persamaan medan teori relativitas umum bagi model alam semesta, Einstein mengajukan "prinsip kosmologi" (agihan materi yang homogen-isotropis).

32 Tentang penggunaan asas estetika, sudah pernah dibahas penulis [lihat Karlina Supelli, "Rasionalitas Sains: Di Antara Tuhan dan Matematika?" dalam Dunia, Tuhan, dan Manusia, ed. Simon L. Tjahjadi (Yogyakarta: Penerbit Kanisius, 2008), hlm. 81-115]. 
teoretis sehingga keduanya mengalami kuantifikasi. Akibatnya ${ }^{\mathrm{R} T}$ menjadi sangat lemah karena teori tidak lagi dapat dibedakan dari sistem formal matematis. Dengan memisah keduanya, predikat observasional tidak mengalami Ramseyfikasi dan maknanya terlepas dari teori sehingga ${ }^{\mathrm{R}} \mathrm{T}$ bukan turunan logis dari kandungan observasional T. ${ }^{33}$ Worrall dan Zahar bahkan juga mempertimbangkan perampatan empiris bisa masuk ke dalam kandungan observasional teori $\mathrm{T}$ sehingga ${ }^{\mathrm{R} T} \mathrm{~T}$ murni bersifat empiris dan tidak dapat diciutkan ke logika atau matematika. ${ }^{34}$ Langkah terakhir ini banyak menerima kritik karena RSE seolah-olah perlu menambah pijakan empirisnya. Padahal, masalah RSE tidak terletak di perampatan empiris tetapi dalam kemampuannya menyediakan argumen yang akan memperlihatkan kesepadanan kognitif ${ }^{\mathrm{R}} \mathrm{T}$ dengan teori.

Bagi Worrall, kemampuan ${ }^{\mathrm{R} T}$ mengangkut semua kemampuan teori $\mathrm{T}$ untuk memberi penjelasan merupakan hal yang jelas dengan sendirinya melalui konsep pengacuan pemerian global. Konsep ini mengatakan bahwa ungkapan-T mengacu ke suatu wujud $X$ jika dan hanya jika $X$ memenuhi pemerian teoretis yang terdapat dalam teori T. Akibatnya, semua pengetahuan kita mengenai wujud teoretis berasal dari peran

33 Bagaimana memilah komponen observasional dan komponen teoretis bukan hal yang sederhana dan sudah menjadi bahan perdebatan sejak Carnap, Hempel, dan lain-lainnya. Dalam kerangka kerja RSE, Zahar menafsirkan kandungan observasional teori dengan menghubungkannya ke kalimat atomik singular yang memerikan peristiwa teramati serta mendukung teori terkait (Zahar, Poincaré's Philosophy, pp. 240-241). Chakravartty masih membuat pembedaan dengan mengusulkan atribut (sifat-sifat dan relasi) yang terhubungkan secara kausal ke alat pelacak (detection properties), dan atribut yang ditambahkan oleh teori tetapi belum disertai dukungan eksperimen yang memadai (auxiliary properties). Masalah dengan pembedaan Chakravartty adalah kemungkinan bahwa komponen heuristik ini, karena kemajuan piranti atau konseptual, dapat beralih menjadi komponen terlacak. Artinya, pemilahan itu merupakan hasil pertimbangan praktis dalam kegiatan keilmuan dan bukan prinsip epistemik [tentang pemilahan ini lihat Anjan Chakravartty, A Metaphysics for Scientific Realism, Knowing the Unobservable (Cambridge: Cambridge University Press, 2007), pp. 47-48].

34 Lihat Zahar and Worrall, Poincaré's Philosophy, pp. 240-246. Zahar menjalankan perampatan untuk isi kalimat observasional (misalnya, besi ini mempunyai massa lebih besar dari pada massa kayu). Kalimat-Ramsey dapat dipertimbangkan sebagai perampatan empiris dari kalimat singular atomik tersebut (semua besi mempunyai massa lebih dari pada massa kayu). Lihat Zahar, "Ramseyfication and Structural Realism," Theoria 19 (2004): 5-30. 
wujud itu di dalam jejaring teori yang mempostulatkannya. Gluon adalah semua hal yang dikatakan oleh teori-teori terbaik tentang gluon. Tidak ada pengacuan dan bahkan pengalaman tentang gluon di luar teori. Sementara itu, kita ingat bahwa ramseyfikasi hanya mengalihkan pemerian teoretis tentang gluon (misalnya, gluon adalah kuanta medan interaksi kuat, tidak bermassa, spin $=1, \ldots$ dan seterusnya...) ke logika tatanan-kedua tanpa melenyapkan kandungan kognitif T. Karena Ramseyfikasi hanya menyisihkan bagian teori yang dalam pertimbangan RSE tidak mempunyai kandungan epistemik, RSE melihat bahwa kalimat-Ramsey dapat mencengkeram semua kemampuan kognitif teori. Dengan kata lain, kalimat-Ramsey itu sendirilah yang menaruh batasan bagi hal-hal yang teramati sekaligus menetapkan bingkai bagi kalimat yang belum teramseyfikasi. Bagi RSE, satu-satunya cara untuk menjelaskan bagaimana wujud teoretis tercantel ke realitas adalah melalui kalimat-Ramsey. Tidak ada jalur epistemik di luar kalimat-Ramsey. ${ }^{35}$

Apakah pertimbangan bahwa ${ }^{\mathrm{R} T}$ dapat sepenuhnya menangkap isi kognitif $\mathrm{T}$ akan membuat setiap teori dengan kalimat-Ramsey yang sama mempunyai daya kognitif yang sepadan? Worrall mengajak kita membandingkan teori Copernicus dan teori Ptolemaios. Pada zamannya, boleh dibilang ${ }^{\mathrm{R}} \mathrm{T}$ kedua teori itu sepadan karena data pendukungnya kurang-lebih sama. Namun teori Copernicus memperlihatkan kelebihan kandungan kognitif kalau dibandingkan dengan teori Ptolemaios karena mampu menjelaskan pelbagai gejala astronomis sebagai konsekuensi logis dari keterpaduan sistem heliosentris. Sedang teori Ptolemaios tidak dapat menjelaskan parameter gerak planet tanpa postulat tambahan. Ptolemaios memerlukan tambahan elemen orbital baru untuk menjelaskan gejala yang berbeda-beda. ${ }^{36}$ Dengan kelebihan kognitif itulah ilmuwan

35 John Worrall, "Miracles and Models," pp. 148, 152. Keterikatan ungkapan teoretis ke teori menimbulkan perdebatan yang panjang dalam filsafat ilmu. Lihat misalnya David Papineau, "Theory-Dependent Terms," Philosophy of Science 63 (Maret 1996): 120.

36 Worrall, "Underdetermination, Realism and Empirical Equivalence," Synthese 180 (2011): 157-172]. 
memilih teori-teori yang mereka nilai lebih baik meskipun konsekuensi obser-vasionalnya tidak berbeda.

\section{RSE DAN METAFISIKA PASCA-CARTESIAN}

Realisme tradisional yang menggunakan kriteria pengacuan semantik tentu sulit menggolongkan RSE sebagai realisme. RSE mau mengatakan bahwa untuk setiap teori $\mathrm{T}$, kalimat-Ramsey ${ }^{\mathrm{R}} \mathrm{T}$ (yang merupakan logika tatanan-kedua) terhubungkan ke struktur $S$ (yang berisi wujud-wujud teoretis dalam T) melalui pernyataan ${ }^{\mathrm{R} T}$ bahwa ada $S$ yang memenuhi T dan jika ${ }^{\mathrm{R} T}$ benar, $S$ memiliki realisasinya di bagian tertentu dunia. $S$ inilah yang membangun landasan kepercayaan RSE. Tolok ukur semantik Putnam yang disebut di bagian awal tulisan ini pun tidak sesuai untuk RSE. Worrall mengakui kesulitan itu tetapi tidak mengajukan tolok ukur non-semantik yang perlu untuk mendukung RSE. Ia hanya merujuk ke tesis metafisis "pascadualisme-Cartesian" yang bunyinya demikian,

Ada realitas yang terstruktur dan akal budi merupakan bagian dari realitas itu; alih-alih memaksakan penataannya kepada segala sesuatu, kerja akal budi hanyalah mengikuti hukum-hukum tetap yang memerikan cara kerja alam. Penulis menerima tesis metafisis ini sebagai sesuatu yang demikian adanya. Penulis menambahkan tesis epistemologis berikut: Sebagian dari realitas terstruktur itu bukan hanya dapat dijangkau oleh manusia, melainkan masuk akal juga untuk percaya bahwa teoriteori yang sukses dalam ilmu-ilmu yang matang, teori terpadu yang menjelaskan gejala tanpa andaian ad hoc, sungguh-sungguh terkancing, menurut cara yang tidak utuh dan berupa pendekatan saja, ke realitas yang terstruktur itu, bolehlah Anda mengatakan [teori-teori] itu mendekati kebenaran. ${ }^{37}$

Dari sudut pandang RSE, hubungan antara teori dan realitas terbentuk melalui struktur matematis teori. Struktur itu "secara garis besar memantulkan realitas tanpa komponen-komponennya harus mengacu

37 John Worrall, "Miracles and Models," pp. 153-154. Tesis metafisis berasal dari Zahar (Zahar, Poincaré's Philosophy, p. 38), tesis epistemologis dari Worrall. 
satu demi satu ke hal-hal yang ada dalam realitas." ${ }^{\prime 38}$ Worrall memandang posisi epistemik inilah yang paling masuk akal dan rendah hati yang masih dapat dipertahankan oleh realis. Boleh jadi Worrall membayangkan struktur matematis teori ibarat sandi bagi struktur yang ada di alam. Apabila struktur matematis itu teruji sepanjang pergantian teori, cukuplah itu menjadi tanda bahwa teori mendekati kebenaran.

Zahar pernah mengusulkan teori kategori dalam matematika sebagai kandidat bagi pengacuan semantik RSE. ${ }^{39}$ Teori kategori digunakan antara lain dalam menafsirkan strukturalisme matematis. Teori ini menjalankan analisis meta-matematika untuk mendapatkan kriteria keajekan dan kesederapan teori-teori matematika. Teori kategori menjadikan relasi sebagai pengertian pangkal (primitive concept) sehingga terbuka peluang untuk membenahi kontradiksi RSE "relasi tanpa relata" melalui pemetaan struktur. Kesulitan yang barangkali akan muncul adalah bagaimana menghubungkan struktur matematis yang sedemikian abstrak dalam teori kategori ke pengacuan struktur kongkret di kawasan fisis. Namun seperti ditunjukkan oleh Muller, sistem pengacuan deskriptif yang memadai bagi RS membutuhkan aksiomatisasi konsep struktur agar menjadi konsep pangkal dan teori kategori tidak memadai untuk keperluan ini. ${ }^{40}$

Kesulitan menyusun tolok ukur bagi RSE melahirkan usulan agar RSE tidak menghubungkan struktur matematis yang bertahan dalam pergantian teori ke struktur nyata di dunia, tetapi ke struktur kesadaran model Kant. Dengan kata lain, struktur matematis yang bertahan itu

38 John Worrall, "Miracles and Models," p. 154.

39 Elie Zahar, Poincare's Conventionalism, p. 38.

40 Teori Kategori sejauh ini baru dimanfaatkan untuk RSO [Jonathan Bain, "Categorytheoretic Structure and Radical Ontic Structural Realism, Synthese 190 (2013): 16211635]. Bdk. Steven French, "The Presentation of Objects and the Repre-sentation of Structure," in Structural Realism: Structure, Object, and Causality, eds. Elaine M. Landry and Dean P. Rickles (Dordrecht: Springer, 2012), pp. 3-28]. Untuk keperluan RSE, teori itu tidak memadai [F.A. Muller, "The Characterisation of Structure: Definition versus Axiomatisation," in The Present Situation in the Philosophy of Science, The Philosophy of Science in a European Perspective, Vol. 1, ed. Friedrich Stadler (Dordrecht: Springer, 2010), pp. 399-416]. 
tidak mengacu tetapi menyediakan syarat-syarat epistemik bagi penegasan yang dapat dipertanggungjawabkan (justified assertibility) mengenai status wujud-wujud itu. ${ }^{41}$ Kiranya kita dapat mereka-reka tanggapan RSE terhadap usulan itu kalau kita memperhatikan dua hal berikut. Pertama, dari kutipan panjang di atas, cukup jelas bahwa Worrall menolak epistemologi Kantian padahal usulan itu memerlukan pendekatan neo-Kantian. Kedua, usulan itu menggolongkan RSE ke dalam realisme dakhil (internal) Putnam. Ini berarti RSE tidak lagi menawarkan argumen kebenaran keilmuan yang dibutuhkan untuk mendukung realisme, melainkan objektivitas pengetahuan. ${ }^{42}$ Satu-satunya yang tersisa dari RSE adalah ontologi dunia dalam bentuk noumena.

Persoalan pengacuan memerlukan kajian tersendiri dan tidak dapat dibahas di sini. Sekarang penulis perlu meninggalkan diskusi di atas untuk meninjau beberapa ilustrasi dalam perkembangan fisika zarah sebagai gambaran sederhana tentang kegiatan keilmuan. Penulis akan mencoba menjawab pertanyaan apakah RSE memadai sebagai model epistemik yang mengemukakan tujuan kegiatan keilmuan.

\section{STRUKTUR ATAU WUJUD?}

Fisika zarah mengalami perubahan yang radikal antara tahun 1950an dan 1970-an. Sesudah Perang Dunia II para fisikawan mengarahkan kegiatan mereka untuk memburu zarah-zarah elementer, yakni zarah paling sederhana yang tidak terbelah lagi. Hasilnya mencengangkan sekaligus membingungkan. Dalam waktu sekitar sepuluh tahun fisikawan menemukan 100-an aneka ragam zarah, sampai-sampai mereka melihat perkembangan fisika zarah seperti kebun yang acak-acakan. Manakah yang merupakan zarah dasar penyusun materi dan interaksi kosmos? Pertanyaan ini tidak mudah dijawab oleh para fisikawan karena teori

41 Michela Massimi, "Strutural Realism: A Neo-Kantian Approach," in Scientific Structuralism, Boston Studies in the Philosophy of Science, Vol. 281, eds. Peter Bokulich and Alisa Bokulich (Dordrecht: Springer, 2011), p. 9.

42 Massimi merujuk ke Hilary Putnam. Bdk. Putnam, Reason, Truth and History (Cambridge: Cambridge University Press, 1981). Bdk. Hilary Putnam, Realism with a Human Face (Cam-bridge, Mass.: Harvard University Press, 1992). 
eletrodinamika kuantum yang dirancang untuk memahami perilaku zarah elementer mewarisi masalah dari fisika klasik. Medan elektromagnetik mengakibatkan massa zarah menjadi tidak berhingga, sesuatu yang jelas tidak masuk akal. Persoalan ini terselesaikan dengan baik lewat program renormalisasi, tetapi beberapa fisikawan, Paul Dirac misalnya, merasa tidak nyaman karena yang ananta seakan-akan disapu ke bawah karpet.

Ada kelompok fisikawan yang malah mengusulkan agar konsep medan kuantum diabaikan saja. Penggerak utamanya adalah Geofrrey Chew dengan sikapnya yang terkenal, kalau medan pion atau nukleon tidak dapat diukur, kita tidak perlu berbicara tentang medan. ${ }^{43}$ Sebagai gantinya adalah program Matriks-S (scattering matrix) yang memperlakukan zarah sebagai semacam epifenomena dari interaksi dinamis antarzarah. Semua zarah mempunyai kedudukan yang sama sebagai relata dalam sktruktur keseluruhan, satu membangun yang lain serta saling membangkitkan sendiri interaksinya. Inilah prinsip "demokrasi nuklir," kata Chew. Sementara Murray Gell-Mann memilih istilah "egalitarianisme zarah." ${ }^{44}$ Kontradiksi antara kedua pendekatan ini memuncak ketika zarah-zarah "elementer" baru terus bermunculan dalam bilik eksperimen fisika.

Pada 1962 Gell-Mann mengusulkan pengelompokan zarah yang ternyata pas dengan kesetangkupan matematika teori grup SU(3) ${ }^{45}$ Ketika

43 Kutipan ini merupakan refleksi Weinberg atas sikap "puritanisme positivistik" [Steven Weinberg, "What is QFT and What did We Think it Was?" in Conceptual Foundations of Quantum Field Theory, ed. Tian Yu Cao (Cambridge: Cambridge University Press, 2004), p. 248].

44 Murray Gell-Mann, Murray Gell-Man: Selected Papers, ed. Harald Fritzsch (London: World Scientific Publishing, 2010), p. 281.

45 Grup SU(N) atau grup uniter khusus (Special Unitary; SU) matra-N SU(N) menunjuk ke grup matriks uniter $N x N$ dengan determinan $=1$. Kesetangkupan bergandeng dengan konsep transformasi yaitu manipulasi matematis terhadap suatu sistem. Dalam sistem yang setangkup, manipulasi tertentu tidak mengubah sifat-sifat sistem yang teramati. Hukum-hukum fisika bagi sebuah sistem yang memiliki kesetangkupan rotasi dan translasi, misalnya, dapat diterapkan dengan cara yang sama dan memberi hasil serupa meskipun kita memutar atau menggeser instrumen. Dalam fisika, kesetangkupan merupakan prinsip yang mendasar karena berkaitan dengan hukum kekekalan. 
berusaha memahami dengan lebih rinci model kesetangkupan itu, GellMann memerlukan wujud matematis untuk melengkapi struktur yang sedang ia bangun. Gell-Mann menamakannya quark. Alih-alih mengikuti saran Chew untuk membuang konsep zarah elementer, Gell-Mann mempertimbangkan quark sebagai wujud yang akan merepresentasikan zarah elementer. ${ }^{46}$ Masalahnya, sifat quark sangat tidak lazim. Quark bukan zarah yang berkelana bebas dan selalu hidup terikat di dalam zarah subatom seperti proton dan netron. Karena kesulitan-kesulitan itu, sikap fisikawan terhadap quark mendua. Gell-Mann sendiri menutup artikelnya tentang quark dengan kalimat yang mengesankan ia sendiri tidak percaya quark akan terealisasi, "pencarian untuk quark yang stabil [tidak terikat dalam zarah subatom] ... akan membantu kita memastikan quark tidak ada (the non-existence of quark)." ${ }^{47}$ Ternyata wujud rekaan itu menemukan realisasinya dalam eksperimen, sesuai ramalan Gell-Mann. Sejak itu fisikawan menemukan quark terdiri dari beberapa jenis. Penemuanpenemuan tersebut meneguhkan Model Standar fisika zarah tentang bangunan dasar yang menyusun materi alam semesta beserta interaksinya.

"Rehabilitasi" teori medan kuantum berlangsung sesudah penemuan zarah omega-minus yang diramalkan oleh Gell-Mann sebelum ia merumuskan model quark. Hal yang menakjubkan bagi Gell-Mann adalah bagaimana kehadiran teori medan tera (gauge field theories) memungkinkan fisikawan bergerak dari konsep kesetangkupan langsung ke perumusan teori yang menjelaskan interaksi zarah dan sifat-sifatnya berdasarkan kesetangkupan itu. ${ }^{48}$ Teori medan tera adalah teori yang menyingkap kesetangkupan interaksi elektromagnetik, lemah, dan kuat

46 Murray Gell-Mann tidak memandang teori medan kuantum bertentangan dengan pendekatan Matriks-S. Selain ia sendiri ikut merumuskan relasi-relasi dispersi yang menjadi landasannya, Matriks-S meminjam teknik-teknik dari teori medan kuantum. Sesudah sempat kehilangan pamor, Matriks-S kini menjadi dasar bagi pengembangan teori dawai.

47 Murray Gell-Mann, Selected Papers, p. 152. Dalam buku populer The Quark and The Jaguar Gell-Mann memprotes komentar banyak penulis "yang saling kutip" dan mengatakan ia tidak percaya quark ada [Murray Gell-Mann, The Quark and the Jaguar (New York: Henry Hold and Company, Inc., 1994), p. 182].

48 Murray Gell-Mann, Selected Papers, p. 30. 
(serta gravitasi) sehingga ilmuwan dapat memahami perilaku zarahzarah elementer. Gell-Man melukiskan perkembangan itu sebagai keberhasilan fisikawan membuat ide tentang keanggunan akur dengan tilikan kualitatif yang penad bagi eksperimen. Fisikawan memandang teori medan tera sebagai representasi kepatuhan alam kepada asas kesetangkupan. Teori itu memperlihatkan bagaimana pada aras terdalam realitas, interaksi fisika terumuskan ke dalam penjelasan yang terpadu.

\section{PENUTUP}

Secara umum, sejarah panjang fisika memperlihatkan pola yang cukup sesuai dengan model RSE. Sejarah ilmu tidak hanya berisi patahan-patahan, tetapi juga kesinambungan teori. RSE dapat digunakan untuk meninjau kesinambungan struktur dalam pergantian teori dan sepanjang kawasan-kawasan fisika dengan gejala-gejala yang secara radikal berbeda, mulai dari kawasan klasik sampai kuantum, baik relativistik maupun non-relativistik. Bagi filosof realis, kesinambungan dalam pergantian menuju teori yang lebih baik menandakan bertambahnya isi pengetahuan sedikit demi sedikit yang kian lama kian mendekati kebenaran. Ilmuwan sendiri kerap tidak nyaman menggunakan kata kebenaran ketika memilih teori. Ilmuwan seperti Poincaré, Duhem dan Mach akan mempertahankan komponen tertentu teori dengan alasan yang lebih pragmatis seperti ketepatan ramalan, ekonomi perhitungan, atau derajat kesuburan teori tanpa menyebut kebenaran.

Terlepas dari keberhasilan itu, RSE belum cukup menampung kandungan kognitif teori. Tidak semua anggota komunitas keilmuan bersikap agnostik terhadap pengetahuan yang melampaui struktur. Dalam praktik keilmuan, pilihan antara struktur dan wujud lebih merupakan pertimbangan metodologis dari pada pembatasan epistemologis yang kaku. Dalam bidang penelitian yang sama sangat boleh jadi ilmuwan menjalankan kedua pendekatan itu - struktur dan wujud-untuk saling menguji. Gell-Mann melangkah dari kesetangkupan ke penemuan quark, sedang James Bjorken dari arah sebaliknya yaitu dari perilaku zarah dan kemudian sampai ke penemuan struktur di dalam proton 
yang tidak lain adalah quark. Kedua pendekatan itu melahirkan teori kuantumkromodinamika, teori medan kuantum yang menjelaskan interaksi kuat dalam zarah subatom. Ilmuwan memperlakukan gejala sebagai bagian dari sistem fisika. Di dalam sistem, pengetahuan tentang relata sama pentingnya dengan pengetahuan tentang relasi.

Situasi di atas membawa kita ke pertanyaan tentang syarat kemungkinan pengetahuan yang melampaui struktur: dapatkah pengetahuan tentang struktur memberi pengetahuan mengenai wujud penopangnya?

Ketika ilmuwan membahas wujud, mereka mengenakan sehimpunan sifat-sifat dasar kepada wujud itu. Sifat-sifat inilah yang mendefinisikan interaksi di antara wujud-wujud tersebut. Bagi wujud kuantum kita memang tidak dapat menerapkan prinsip individuasi menurut kategori klasik. ${ }^{49}$ Kita tidak dapat mengatakan "elektron ini" atau "muon itu." Dua elektron yang berpasangan dapat bertukar posisi tanpa menimbulkan perubahan fisika yang dapat dilacak. Meski demikian, elektron bukanlah elektron kecuali memiliki massa, muatan dan spin tertentu. Ketiga-tiganya merupakan sifat intrinsik zarah elementer dan status ontologisnya sejajar dengan struktur. Zarah kuantum juga dapat dicacah untuk mengetahui sifat agihannya. Dalam kawasan kuantum, kita menerima status pengetahuan tentang wujud sebagai pengetahuan tentang jenis (kind) dan bukan objek seperti meja A, kursi B, jendela C, dan seterusnya. Pengetahuan ini hanya menghasilkan pengetahuan taksonomis dan bukan identitas partikular, tetapi ilmuwan dapat mengatakan bahwa elektron mempunyai sehimpunan sifat sehingga identitasnya berbeda dengan muon, kendati keduanya sama-sama merupakan keluarga lepton. ${ }^{50}$

49 Diskusi mengenai kemungkinan wujud kuantum masuk ke dalam kategori objek dapat dilihat dalam Simon Saunders, "Are Quantum Particles Objects?" Analysis 66 (2006): 52-63. Bdk. Steven French and D. Krause, Identity in Physics: A Formal, Historical and Philosophical Approach (Oxford: Oxford University Press, 2006).

50 Pada tahun 1960-an para fisikawan berhasil mengelompokkan semua zarah ke dalam dua keluarga besar berdasarkan interaksinya, yakni keluarga lepton (elektron, muon dan neutrino serta anti-zarahnya) dan sisanya kecuali foton masuk ke dalam keluarga hadron. Keluarga hadron dibagi lagi berdasarkan nilai spin menjadi baryon dan meson 
Pengetahuan itu cukup untuk menjamin kemungkinan realisme yang lebih luas, misalnya dalam bentuk realisme keilmuan kritis (RKK) ataupun semirealisme. Kedua bentuk realisme ini, di satu pihak, melampaui pesimisme RSE mengenai wujud dan di lain pihak melampaui pesimisme realisme wujud (entity realism) akan teori/hukum secara umum. Keduanya menerima wujud sebagai realitas mandiri dan memperlakukan struktur sebagai bingkai yang mengandung pengetahuan tentang wujud. Bedanya RKK memperlakukan teori yang memaparkan wujud secara bisa salah (fallible), sedang semirealisme memperlakukannya secara lebih skeptik dengan memberi penafsiran minimal. ${ }^{51}$ RKK melampaui pesimisme Laudan karena dalam menilai kemajuan teori, RKK berpegang ke derajat peningkatan teori mendekati kebenaran (verisimilitude). Dengan demikian ilmuwan dapat mengatakan bahwa teori-teori yang baik, pun ketika akhirnya dinyatakan salah, mengandung kebenaran lebih tinggi dari pada teori-teori sebelumnya. ${ }^{52}$

Berdasarkan sifat statistiknya, semua zarah itu dibagi ke dalam kelompok fermion dan boson. Sesudah Gell-Mann memperkenalkan quark, struktur zarah dikemukakan dengan menggunakan quark. Struktur proton dapat ditulis $(u u d)$, netron $(u d d)$, dan seterusnya.

51 Realisme wujud menerima relasi kausal yang ditimbulkan oleh wujud-wujud yang dipostulatkan teori terhadap piranti laboratorium, tetapi secara umum menolak realisme menyangkut hukum-hukum fisika dan teori. Realisme wujud dikembangkan antara lain oleh Nancy Cartwright, Ian Hacking (1983) dan Ronald Giere (1988) [Lihat Nancy Cartwright, How the Laws of Physics Lie (Oxford: Oxford University Press, 1983)]. Semirealisme yang merupakan penggabungan antara RS dan realisme wujud dikembangkan oleh Anjan Chakravartty dengan mengambil penafsiran minimal atas struktur (Chakravartty, A Metaphysics for Scientific Realism, Ch. II).

52 RKK menerima peran ontologi dalam ungkapan teoretis tanpa mengabaikan matra konstruktif pengetahuan. Karena lapis realitas yang membangkitkan mekanisme tidak teramati langsung, RKK menerapkan logika abduksi sebagai langkah penyimpulan selain induksi dan deduksi. RKK bertolak terutama dari pemikiran Charles Sanders Peirce dan Karl Popper. Kesulitan yang masih dihadapi RKK adalah mengembangkan konsep verisimilitude yang lebih memadai dari pada konsep Popper tanpa jatuh ke relativisme karena "kemiripan teori dengan kebenaran" tidak dapat dilepaskan dari bingkai epistemik dan linguistik teori. Untuk rujukan lihat catatan kaki no. 7 di atas; Bdk. Karl-Otto Apel, "Pragmatism as Sense-Critical Realism Based on a Regulative Idea of Truth: In Defense of a Peircean Theory of Reality and Truth," Transactions of the Charles S. Peirce Society 37 (2001): 443-474. 
Jika argumen di atas diterima, tampak bahwa RSE sebetulnya hanya menyodorkan separuh gambar untuk dapat mendukung argumen realisme. Bahwa pengetahuan teoretis tentang wujud sewaktu-waktu dapat ditunjukkan salah, tidak cukup untuk melemahkan status epistemiknya dalam upaya memahami alam semesta. Bagi banyak ilmuwan, sejauh wujud teoretis membantu upaya memahami gejala, sejauh interaksinya (secara prinsip) dapat dilacak dan sejauh diperlukan untuk menghasilkan peramalan maka tilikan atas wujud merupakan unsur yang berharga bagi pengetahuan. Dalam kegiatan keilmuan, pemilahan antara wujud teoretis dan wujud observasional ataupun relasi dan relata bukan pagar epistemik yang memastikan mana komponen teori yang dapat dikenai nilai kebenaran dan mana yang tidak.

RSE adalah realisme keilmuan yang rendah hati. RSE menerima tesis utama realisme tetapi juga belajar dari sejarah ilmu sehingga para pendukung RSE merasa perlu membatasi komitmennya. Dalam kaitan dengan kesuksesan mekanika kuantum, misalnya, posisi RSE dapat dilihat dari pernyataan Worrall, "Realis strutural hanya menegaskan ... berdasarkan kesuksesan empiris teori [kuantum], struktur alam semesta boleh jadi menyerupai struktur mekanika kuantum. Adalah suatu kekeliruan kalau kita berpikir kita perlu mengerti hakikat kuantum." ${ }^{53}$ Meski demikian, sejarah ilmu juga memberi kita cukup alasan untuk mengatakan bahwa ilmu-ilmu empiris mempunyai tujuan yang lebih dari pada sekadar menangkap struktur formal teori dan mencari padanannya dalam alam.

Tepat di sinilah kita melihat perbedaan tugas antara ilmuwan dan filosof. Seperti kata Ernan McMullin, realisme bukan prinsip regulatif dan realisme tidak dimaksudkan sebagai strategi bagi para ilmuwan. Realisme juga tidak akan gugur seandainya teori tentang peluruhan radioaktif salah. ${ }^{54}$ Filsafat ilmu berisi upaya untuk mengenali ciri-ciri

53 John Worrall, Structural Realism, p. 123.

54 Ernan McMullin, "A Case for Scientific Realism," in Philosophy of Science, Contemporary Readings, eds. Yuri Balashov and Alex Rosenberg (London: Routledge, 2002), p. 273. 
pengetahuan keilmuan dan cara pemerolehannya, sehingga filosof dapat menyusun model penjelasan terbaik tentang kemajuan/kegagalan ilmu. Filsafat ilmu memusatkan perhatiannya ke gagasan-gagasan keilmuan yang berkembang lalu meletakkannya ke dalam bingkai meta-teori yang sederap dan taat asas untuk menjelaskan kegiatan keilmuan, serta memahami gambar dunia yang dihadirkan ilmu. Karena itu kita perlu melihat RSE melalui bingkai kerja filsafat, dan bukan melalui bingkai kerja keilmuan. Bagi filosof ilmu, pertanyaannya adalah bagaimana menempatkan fisika dan temuan-temuannya ke dalam bingkai pemahaman metafisis yang memadai mengenai struktur dan wujud alami. Dalam menjalankan analisisnya, tentu filsafat ilmu tidak dapat mengabaikan praktik aktual keilmuan.

RSE yang diprakarsai oleh Worrall dan Zahar memberi sumbangan yang berharga bagi filsafat ilmu. RSE mengingatkan realis agar berhatihati dan cermat ketika mencoba menarik hubungan antara kesuksesan dan kebenaran teori. RSE juga menunjukkan bahwa realis tidak perlu mempercayai seluruh bangunan teori dan masih dapat menjadi realis. Dalam teori selalu ada unsur konvensi, konstruksi, spekulasi, dan lain sebagainya. Konvensi bisa keliru, konstruksi dapat salah dan spekulasi dapat menjadi terlalu liar. Pilihan RSE untuk menaruh komitmen epistemiknya ke struktur matematis merupakan jalan keluar yang aman untuk menanggapi sikap pesimistik atau skeptisme antirealis_-sebuah sikap yang dalam bentuk ekstrim dapat membuahkan pertimbangan tidak manusiawi. ${ }^{55}$ Hanya saja, dari perspektif realis tradisional, pilihan RSE untuk memperlakukan wujud takteramati sebagai "noumena" membuat bingkai epistemiknya menjadi terlalu kurus dan sulit menampung upaya

55 Lihat, misalnya, kritik Meera Nanda terhadap kesimpulan Stephen Marglin yang menyatakan bahwa "setiap kepercayaan menciptakan kebenarannya sendiri." Kesimpulan ini melahirkan pertimbangan bahwa ilmu kesehatan modern tidak penad dan tidak dapat dipakai untuk menilai praktik budaya berupa mutilasi genital perempuan [Meera Nanda, "The Epistemic Charity of the Social Constructivist Critics of Science and Why the Third World Should Refuse the Offer," in A House Built on Sand, Exposing Postmodern Myths about Science, ed. Noretta Koertge (Oxford: Oxford University Press, 1998), p. 301]. 
ilmu menyeberangi jurang lebar antara teori dan kebenaran. Namun realisme tradisional juga tidak memadai karena kurang memperhitungkan matra sosial kegiatan keilmuan.

RSE dapat menjadi lebih gemuk jika menurunkan konsep struktur ke wujud dan menyatakan bahwa pengetahuan tentang wujud juga mengambil bentuk struktur. Hanya saja, menjelaskan relata sebuah relasi dengan relasi-relasi yang lain membawa risiko regressus ad infinitum. Kecuali, RSE bersedia mengambil posisi radikal sebagaimana tawaran RSO dengan meniadakan sepenuhnya kategori wujud dan hanya menerima struktur sebagai satu-satunya ontologi dunia. Kemungkinan yang lebih menjanjikan ketimbang RSO adalah realisme keilmuan kritis atau semirealisme yang lebih lentur. Keduanya sudah disinggung di atas tetapi belum menemukan ruang yang cukup untuk dibahas di sini. Dari kacamata keduanya, RSE merupakan posisi epistemologis yang tepat tetapi kegiatan keilmuan menunjukkan bahwa hukum-hukum fisika dan ontologinya tidak dapat diceraikan begitu saja. Tugas keduanya adalah melibatkan pengetahuan tentang wujud tanpa terlalu menggelembungkan metafisika. Kemungkinan ketiga adalah menggunakan strukturalisme sebagai kerangka kerja (realisme struktural metodologis) untuk menghadirkan struktur dan wujud yang ada di dunia ke dalam teori. Kemungkinan ketiga menarik bagi ilmuwan tetapi kurang menarik bagi para metafisikawan.

Berbeda dengan kecenderungan sepanjang paruh pertama abad ke20, filsafat ilmu tidak lagi dapat mengabaikan metafisika terutama dalam diskusi-diskusinya mengenai realisme keilmuan. Dalam kaitan antara filsafat dan ilmu, pertanyaan bagi realisme struktural adalah seberapa gemuk/kurus metafisika yang kita perlukan untuk memahami struktur dunia yang dikemukakan oleh ilmu?

"Anda tidak perlu menaruh terlalu banyak untuk mendapat lebih," kata Gell-Mann kepada fisikawan muda. ${ }^{56}$ Tampaknya RSE mengikuti nasihat itu terlalu banyak sehingga menaruh terlalu sedikit. 


\section{DAFTAR RUJUKAN}

Apel, Karl-Otto. "Pragmatism as Sense-Critical Realism Based on a Regulative Idea of Truth: In Defense of a Peircean Theory of Reality and Truth," Transactions of the Charles S. Peirce Society 37 (2001): 443-474.

Apffel-Marglin, Frederique. "Smallpox in Two Systems of Knowledge," UNU/Wider Planning Meeting on Systems of Knowledge as Systems of Domination. Juli 1987. Reprinted in Dominating Knowledge: From Development to Dialogue, eds. Frederique Apffel-Marglin and Stephen A. Marglin. Oxford: Oxford University Press, 2001, pp. 102-144.

Bain, Jonathan. "Category-theoretic Structure and Radical Ontic Structural Realism. Synthese 190 (2013): 1621-1635.

Boyd, Richard. "On The Current Status of Scientif Realism." In The Philosophy of Science, eds. Richard Boyd, Philip Gasper, J. D. Trout. Cambridge, Mass.: MIT Press, 1991, pp. 195-222.

Braddon-Mitchell, David, Robert Nola, eds. Conceptual Analysis and Philosophical Naturalism. Cambridge, Massachusetts: MIT Press, 2009.

Cartwright, Nancy. How the Laws of Physics Lie. Oxford: Oxford University Press, 1983.

Cassirer, Ernst. Substance and Function and Einstein's Theory of Relativity. Chicago: The Open Court Publishing Company, 1923.

Demopoulos, William and M. Friedman. “Critical Notice: Bertrand Russell's The Analysis of Matter: Its Historical Context and Contemporary Interest." Philosophy of Science 52 (1985): 621-639.

Duhem, Pierre. The Aim and Structure of Physical Theory, trans. Philip P. Wiener. Princeton: Princeton University Press, (1906) 1954.

English, Jane. “Underdetermination: Craig and Ramsey." Journal of Philosophy 70 (1973): 453-462.

Feyerabend, Paul. Realism, Rationalism, and Scientific Method: Philosophical Papers, Vol. 1. Cambridge: Cambridge University Press, 1981.

French, Steven. "The Presentation of Objects and the Representation of Structure." In Structural Realism: Structure, Object, and Causality, eds. Elaine M. Landry and Dean P. Rickles. Dordrecht: Springer, 2012, pp. 3-28.

French, Steven, D. Krause. Identity in Physics: A Formal, Historical and Philosophical Approach. Oxford: Oxford University Press, 2006. 
French, Steven, Juha Saatsi. "Realism about Structure: The Semantic View and Non-linguistic Representations." Philosophy of Science 73, Proceedings of the 2004 Biennial Meeting of The Philosophy of Science Association Part II: Symposia Papers (December 2006): 548-559.

Gell-Mann, Murray. Murray Gell-Man: Selected Papers, ed. Harald Fritzsch. London: World Scientific Publishing, 2010.

The Quark and the Jaguar. New York: Henry Hold and Company, Inc., 1994.

Giere, Ronald N. Explaining Science: A Cognitive Approach. Chicago: University of Chicago Press, 1988.

Hacking, Ian. Representing and Intervening. Cambridge: Cambridge University Press, 1983.

Hempel, Carl. "The Theoretician's Dilemma: A study in the Logic of Theory Construction." In Minnesota Studies in the Philosophy of Science, eds. H. Feigl, M. Scriven and G. Maxwell, Vol. 2. Minneapolis: Univer-sity of Minnesota Press, 1958, pp. 37-98.

Ketland, Jeffrey. "Empirical Adequacy and Ramsification." The British Journal for the Philosophy of Science 55 (June 2004): 287-300.

Kuhn, The Road since Structure. Chicago: Chicago University Press, (1970) 2000.

Ladyman, James, D. Ross. “Ontic Structural Realism and the Philosophy of Physics." In Everything must Go: Metaphysics Naturalized, eds. James Ladyman and Don Ross, Oxford: Oxford University Press, 2007, pp. 130-189.

Laudan, Larry. "A Confutation of Convergent Realism." Philosophy of Science 48 (1981): 19-49.

McMullin, Ernan. “A Case for Scientific Realism.” In Philosophy of Science, Contemporary Readings, eds. Yuri Balashov and Alex Rosenberg. London: Routledge, 2002, pp. 248-281.

Massimi, Michela. "Strutural Realism: A Neo-Kantian Approach." In Scientific Structuralism, Boston Studies in the Philosophy of Science, eds. Peter Bokulich and Alisa Bokulich, Vol. 281. Dordrecht: Springer, 2011, pp. 1-23.

Maxwell, Grover. "Structural Realism and the Meaning of Theoretical Terms." Minnesota Studies in the Philosophy of Science 4 (1971): 181192. 
Muller, F. A. "The Characterisation of Structure: Definition versus Axiomatisation." In The Present Situation in the Philosophy of Science, The Philosophy of Science in a European Perspective, ed. Friedrich Stadler, Vol. 1. Dordrecht: Springer, 2010, pp. 399-416.

Nanda, Meera. "The Epistemic Charity of the Social Constructivist Critics of Science and Why the Third World Should Refuse the Offer." In $A$ House Built on Sand, Exposing Postmodern Myths about Science, ed. Noretta Koertge. Oxford: Oxford University Press, 1998, pp. 286-311.

Newman, M. H. A. "Mr. Russell's "Causal Theory of Perception.” Mind, New Series 37 (April 1928): 137-148.

Newton, Isaac. "General Scholium." Mathematical Principles of Natural Philosophy, trans. Andrew Motte. New York: Daniel Adee, (1729) 1846.

Niiniluoto, Ilkka. "Verisimilitude: The Third Period." British Journal for the Philosophy of Science 49 (1998): 1-29.

Nussbaum, Martha C. Sex and Social Justice. Oxford: Oxford University Press, 1999.

Papineau, David. The Philosophy of Science. London: Oxford University Press, 1996.

. “Theory-Dependent Terms." Philosophy of Science 63 (March 1996): 1-20.

Poincaré, Henri. "Science and Hypotheses." In The Foundations of Science, trans. George Bruce Halsted. New York: The Science Press, (1903) 1913, pp. 9-353.

Popper, Karl. Conjectures and Refutations. New York: Basic Books, (1962) 2002.

2002.

The Logic of Scientific Discovery. London: Routledge, (1959)

Psillos, Stathis. "Agnostic Empiricism versus Scientific Realism: Belief in Truth Matters." International Studies in the Philosophy of Science 14 (2000): 57-75. $253-279$.

. “Carnap, The Ramsey-Sentence." Erkenntnis 52 (2000):

"Is the History of Science the Wasteland of False Theories?" In Adapting Historical Knowledge Production to the Classroom, eds. P. V. Kokkotas, K. S. Malamitsa, and A. A. Rizaki. Rotterdam: Sense Publishers, 2011, pp. 17-36. 
. "Is Structuralism the Best Possible Worls?" Dialectica 49 (1995): 15-46.

. Knowing the Structure of Nature. New York: Palgrave, MacMillan, 2009.

Scientific Realism: How Science Tracks Truth. London: Routledge, 1999.

Putnam, Hilary. Mathematics, Matter and Method: Philosophical Papers, Vol. 1. London: Cambridge University Press, 1975. . Meaning and the Moral Sciences. London: Routledge, 1978. . Realism with a Human Face. Cambridge, Mass.: Harvard University Press, 1992.

. Reason, Truth and History. Cambridge: Cambridge University Press, 1981.

Saunders, Simon. "Are Quantum Particles Objects?" Analysis 66 (2006): 52-63.

Sismondo, Sergio. "Science and Technology Studies and an Engaged Program." In The Handbook of Technology and Science Studies, eds. Edward J. Hackett, Olga Amsterdamska, Michael Lynch, and Judy Wajcman. Cambridge, MA: MIT Press, 2008, pp. 13-32.

Sklar, Lawrence. Philosophy and the Foundations of Dynamics. Cambridge: Cambridge University Press, 2013.

Supelli, Karlina. "Ilmuwan dan Problem Epistemik Ruangwaktu." Diskursus 4 (April 2005): 19-27.

. "Rasionalitas Sains: Di Antara Tuhan dan Matematika?" dalam Dunia, Tuhan, dan Manusia, ed. Simon L. Tjahjadi. Yogyakarta: Penerbit Kanisius, 2008, hlm. 81-115.

Weinberg, Steven. "What is QFT and What did We Think it Was?" In Conceptual Foundations of Quantum Field Theory, ed. Tian Yu Cao. Cambridge: Cambridge University Press, 2004, pp. 241-251.

Worrall, John. "Miracles and Models: Why Reports of the Death of Structural Realism May Be Exaggerated." Philosophy of Science. Royal Institute of Philosophy Supplement, Vol. 61, ed. Anthony O'Hear (October 2007): 125-154.

. "Scientific Realism and Scientific Change." The Philosophical Quarterly 32. Special Issue: Scientific Realism (July 1982): 201-231. . "Structural Realism: The Best of Both Worlds." Dialectica 43 (1989): 99-124. 
. “Underdetermination, Realism and Empirical Equivalence." Synthese 180 (2011): 157-172.

Zahar, Elie. Poincaré's Philosophy: From Conventionalism to Pheno-menology. Chicago: Open Court, 2001.

. "Ramseyfication and Structural Realism." Theoria 19 (2004): 5-30.

. “Why Did Einstein's Programme Supersede Lorentz's? (I)." The British Journal for the Philosophy of Science 24 (June, 1973): 95-123. 